\title{
Toward Healthy Balance Sheets: Are Savings Accounts a Gateway to Young Adults' Asset Diversification and Accumulation?
}

\author{
Terri Friedline, Paul Johnson, and Robert Hughes
}

\begin{abstract}
Understanding the balance sheets of today's young adults-particularly the factors that set them on a path to financial security through asset diversification and accumulation-lends some insight into the balance sheets they will have when they are older. This study uses panel data from the Census Bureau's 1996 Survey of Income and Program Participation to investigate the acquisition of a savings account as a gateway to asset diversification and accumulation for young adults. Two avenues were considered: The first emphasized ownership of a diverse portfolio of financial products, and the second emphasized the accumulated value of liquid assets. Almost half of the surveyed young adults owned a savings account ( 43 percent) and approximately 3 percent acquired a savings account over the course of the panel. (Older, nonwhite, or unemployed participants were significantly less likely to acquire an account.) Those who owned or acquired a savings account also had more diverse asset portfolios. Evidence suggests that young adults who acquire a savings account and diversify their asset portfolios may also accumulate more liquid assets over time, which can be leveraged in the future to strengthen their balance sheets. (JEL D1, D3, D140)
\end{abstract}

Federal Reserve Bank of St. Louis Review, Fourth Quarter 2014, 96(4), pp. 359-89.

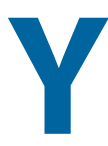
oung adulthood is a period often characterized by financial fragility. Young adults earn the lowest incomes of their careers while making decisions about obtaining postsecondary education, living independently, finding and changing employment, and repaying educational debt (Bell et al., 2007, and Mishel et al., 2012). They may also have limited assets on which to draw during times of financial need, given that half of young adults through age 40 lack sufficient accumulated assets to sustain themselves above the poverty line for three months without regular income (Rank and Hirschl, 2010). One study finds that the average savings account balance of young adults is generally low, from $\$ 639$ to $\$ 1,881$ between 16 and 35 years of age (Friedline and Nam, 2014). This low average suggests

\footnotetext{
Terri Friedline is an assistant professor at the School of Social Welfare and faculty associate with the Assets and Education Initiative; Paul Johnson is a professor of political science and associate director of the Center for Research Methods and Data Analysis; and Robert Hughes is a doctoral student in the department of sociology, University of Kansas. This paper was prepared for the symposium "The Balance Sheets of Younger Americans: Is the American Dream at Risk?" presented May 8 and 9, 2014, by the Center for Household Financial Stability and the Research Division at the Federal Reserve Bank of St. Louis and the Center for Social Development at Washington University in St. Louis.

( ) 2014, The Federal Reserve Bank of St. Louis. The views expressed in this article are those of the author(s) and do not necessarily reflect the views of the Federal Reserve System, the Board of Governors, or the regional Federal Reserve Banks. Articles may be reprinted, reproduced, published, distributed, displayed, and transmitted in their entirety if copyright notice, author name(s), and full citation are included. Abstracts, synopses, and other derivative works may be made only with prior written permission of the Federal Reserve Bank of St. Louis.
} 


\section{Friedline, Johnson, Hughes}

young adults may have limited savings for even daily, lower-level financial needs such as groceries, bills, rent, or auto repairs, let alone needs arising from educational debt or independent living that persist for several months or years.

It is generally agreed that balance sheets consist of assets, debt, and net worth (Boshara, 2012; Key, 2014; Mishkin, 1978), with an underlying assumption that saving, diversifying, and accumulating assets lead to healthier balance sheets (Carasso and McKernan, 2007). Young adults with lower accumulated liquid assets may have fragile balance sheets when healthy balance sheets are most needed. If young adults enter this period of life by accumulating reserves and liquid assets through financial products such as savings, stock, and retirement accounts, they may have the financial resources to better weather unexpected changes in employment or living situations or to further invest in their futures. Their savings and liquid assets help to create a healthy balance sheet that likely sets them on a path to financial security from which they can benefit throughout life. Understanding the savings and liquid assets of today's young adults as part of their balance sheets lends some insight into their balance sheets when they are older, particularly with regard to factors that set them on a path to financial security and, eventually, mobility.

In this article, we attempt to provide an understanding of assets as one component of the balance sheets of today's young adults - that is, understanding the starting point for young adults to acquire lifetime financial security. Given that savings accounts are one of the most basic products available from mainstream financial institutions and are hypothesized as a starting place or gateway to asset diversification and accumulation (Friedline and Elliott, 2013; Hogarth and O'Donnell, 2000; Sherraden, 1991; Xiao and Noring, 1994), this articles seeks to provide a better understanding of the role of savings accounts in young adults' balance sheets, particularly with regard to a diverse portfolio and the accumulation of liquid assets.

\section{A SAVINGS ACCOUNT AND THE FINANCIAL HIERARCHY OF A DIVERSE PORTFOLIO}

Xiao and Anderson (1997) draw on Maslow's $(1948,1954)$ human needs theory to show how the financial products acquired by young adults may ascend a hierarchy based on the needs the products are designed to meet. Human needs are assumed to be hierarchical, with the achievement of higher-level needs conditional on the achievement of lower-level needs (Maslow, 1948, 1954). These assumptions have been applied to the acquisition and use of financial products as they relate to lower- and higher-level needs (Xiao and Anderson, 1997; Xiao and Noring, 1994; Xiao and Olson, 1993). Notably, lower-level needs are referred to as "survival" and higher-level needs are referred to as "growth" (Xiao and Anderson, 1997), ${ }^{1}$ labels that also provide some indication of the achievement of financial security. From this perspective, a savings account is one of the first and most common financial products acquired because it is lower risk, easily liquidated, and designed for the achievement of daily, lower-level needs. Financial products such as stock and retirement accounts entail higher risk, have liquidity constraints, and are designed for long-term investments and higher-level needs. 
Young adults may ascend a financial hierarchy by acquiring a savings account that facilitates their achievement of daily, lower-level needs such as buying groceries or paying utility bills. Once acquired, young adults' maintenance of their savings account to continue to meet lower-level needs may be guided in part by the inertia of behaviors regarding financial products (Benartzi and Thaler, 2007, and Madrian and Shea, 2001). As young adults transition to achieving long-term, higher-level needs, such as affording college tuition, the down payment on a new home, or inheritances they can provide to future generations, they may acquire stock and retirement accounts. A diverse portfolio, then, potentially indicates that young adults have ascended the financial hierarchy (De Brouwer, 2009; Canova, Rattazzi, and Webley, 2005; Xiao and Anderson, 1997). This trend toward diversification is consistent with an optimal portfolio arrangement that spreads potential risk across multiple assets (Fabozzi, Gupta, and Markowitz, 2002, and Markowitz, 1952), although the extent of diversification of most asset portfolios is generally limited (King and Leape, 1998).

\section{A GATEWAY TO HEALTHY BALANCE SHEETS}

The financial products acquired by young adults as they ascend the financial hierarchy may serve as a gateway to diversifying and accumulating assets, nudging them toward healthy balance sheets. Young adults can leverage the assets accumulated in a diverse asset portfolio to their advantage for generating additional wealth throughout life (Friedline, Despard, and Chowa, forthcoming; Friedline and Song, 2013; King and Leape, 1998). As such, a diverse portfolio may be an indicator of the ascension of the financial hierarchy to achieve higher-level needs, and the contribution of accumulated assets across the portfolio may be an indicator of financial security (Beutler and Dickson, 2008; Canova, Rattazzi, and Webley, 2005; Xiao and Anderson, 1997). Holding a majority of liquid assets in a savings account might indicate the need for easily liquidated assets, which might allude to inadequate funds to afford daily, lowerlevel needs. A majority of assets in stock or retirement accounts would be more complicated to liquidate and might indicate the existence of adequate funds to meet daily expenses and therefore represent investment in higher-level needs.

Research confirms a decrease in accumulated amounts in savings accounts as assets increase (Xiao and Anderson, 1997); this suggests the contributions of the portfolio to asset accumulation change with ascending the financial hierarchy. From this perspective, a savings account may serve as a gateway for ascending the financial hierarchy as demonstrated by the distribution of accumulated assets across the portfolio. For example, the amount held in a savings account contributes the most to accumulated liquid assets for households at the bottom 10 percent of the asset distribution compared with the amounts held in stock and retirement accounts for households at the top 10 percent of the distribution (Xiao and Anderson, 1997). Likewise, the most common trajectory from asset diversification to accumulation is to begin by accumulating assets in savings and checking accounts in early young adulthood and progress by accumulating assets through homeownership and stocks (Keister, 2003). It is much less common for young adults to begin by accumulating assets in homes and stocks.

The ascension of the financial hierarchy and distribution of accumulated assets could be interpreted to mean that asset diversification must always precede accumulation. However, 


\section{Friedline, Johnson, Hughes}

the relationship between diversification and accumulation is likely more nuanced. In writing about the optimal portfolio arrangement, Sherraden (1990, p. 589) states "With greater assets, a household can more effectively diversify its holdings," suggesting instead that asset accumulation precedes diversification. The question of "Which came first, a diverse portfolio or accumulated assets?" is somewhat less perceptive than the question of "How does a diverse portfolio contribute to the value of accumulated assets?" Whereas the first question focuses on determining the causal direction of the relationship, the latter explores the correlation or pattern and composition of assets accumulated within the context of a diverse portfolio. In other words, compared with young adults with either no account or only a savings account, young adults who own both savings and retirement accounts may be more financially secure and have a healthier balance sheet based on their accumulated liquid assets. This is because a savings account may represent lower-level needs, whereas savings and retirement accounts represent lower- and higher-level needs. If young adults acquire financial products contingent on a financial hierarchy that eventually develops into a diverse portfolio that can be leveraged to generate additional assets, then it is worth knowing how a diverse portfolio contributes to the balance sheet.

\section{RESEARCH QUESTIONS}

This article addresses the following questions to better understand how young adults acquire a savings account and the role account acquisition plays in diversifying and accumulating assets:

(i) What relates to the acquisition, or take-up, of a savings account by young adults after controlling for relevant factors?

(ii) Once a saving account is acquired, what fraction of young adults acquire other financial products such as CDs, stock, and retirement accounts? In other words, is the acquisition of a savings account a gateway to a diverse asset portfolio for young adults?

(iii) How much do the acquisition of a savings account and a diverse asset portfolio by young adults contribute to the value of their accumulated liquid assets after controlling for relevant factors?

\section{METHODS}

\section{Data}

A large sample providing information at multiple and frequent time points was needed to analyze the acquisition of a savings account, asset diversification, and asset accumulation among a young adult population over time. The Panel Study of Income Dynamics (PSID) and Survey of Consumer Finances (SCF) are often used to explore questions about wealth (including savings and assets; Curtin, Juster, and Morgan, 1989; Czajka, Jacobson, and Cody, 2003; Wolff, 1999). However, these surveys have smaller sample sizes and an analysis can 
measure savings and assets only every other year at most, potentially missing sensitive changes that occur monthly or quarterly. This study used data from the 1996 panel of the Survey of Income and Program Participation (SIPP) that were collected and made publicly available by the Census Bureau. The 1996 SIPP data were collected during the 1990s, a decade of U.S. economic growth (Jorgenson, Ho, and Stiroh, 2008). Thus, the questions and data explored in this article reflected balance sheets during generally favorable economic conditions (when the balance sheets of young adults might appear the most optimistic). ${ }^{2}$

Between December 1995 and February 2000, the 1996 SIPP drew a random sample of households grouped within geographic regions based on population counts from the most recent Census (U.S. Census Bureau, 2011), oversampling those with lower incomes ( $N=380,609$ individual respondents from 40,188 eligible households; $n=1,634,357$ number of rows). Each household member 15 years of age and older participated in data collection, which occurred either quarterly or three times per year. During each interview, respondents recalled their experiences over the previous four months, thus resulting in 12 observations per year for a 48-month time span on many variables. This allowed construction of monthly and quarterly histories of savings and asset diversification accounts of young adults for up to 48 months, which was ideal for addressing the research questions. Quarterly information was drawn from the fourth month in the reference period when respondents were interviewed in person, allowing examination of changes in responses from one quarter to the next. The 1996 SIPP also collected annual information in topical modules on special topics, including health, education, child care, and accumulated assets. Annual information on liquid assets was collected in topical modules during waves $3,6,9$, and 12 over the 48 -month panel.

Sample selection criteria included young adults between 18 and 40 years of age who provided reference month and topical module information and participated in at least two years' worth of data collection. Separate samples were produced from these two sources of information. Thus, a young adult who entered the sample at age 16 was included when he or she provided at least two years' worth of information, making him or her age 18 at some time during the sampling frame. Likewise, two years' worth of information was retained for a young adult who entered the sample at age 40 , making him or her age 42 at some time during the sampling frame. In other words, young adult respondents were included when age 18 would not be their last year of eligibility and when age 40 would not be their first year of eligibility. This restriction minimized the inclusion of young adults who cycled in or out of the 1996 SIPP within a shorter time, ensured more equal sample sizes across age groups, and reduced the number of available rows in the data to 1,245,689 (a reduction of 24 percent). Based on these selection criteria, a total of 311,446 person-month observations for young adults were included in the reference month sample ( $n=30,601$ individuals). There were 36,415 individuals included in the topical module sample and 100,998 rows of data. This reduction in rows of data for the topical module sample was expected given that the sample was followed on an annual basis as opposed to monthly or quarterly.

The average age of young adults was 30; 48 percent of respondents were female and 82 percent were white. Smaller percentages of Asians (4 percent) and other nonwhite groups (14 percent; blacks, Native Americans/First Peoples) were represented. Forty-three percent of 
Friedline, Johnson, Hughes

\section{Table 1}

\section{Sample Characteristics}

\begin{tabular}{|c|c|c|}
\hline Covariates & $\begin{array}{c}\text { Reference month sample } \\
(n=30,601) \\
\text { Mean (SD)/percent }\end{array}$ & $\begin{array}{c}\text { Topical module sample } \\
(n=36,415) \\
\text { Mean (SD)/percent }\end{array}$ \\
\hline \multicolumn{3}{|l|}{ Sex } \\
\hline Male & 52 & 54 \\
\hline Female & 48 & 46 \\
\hline \multicolumn{3}{|l|}{ Race } \\
\hline White & 82 & 82 \\
\hline Nonwhite & 14 & 14 \\
\hline Asian & 4 & 4 \\
\hline Marital status & 50 & 50 \\
\hline Married & 50 & 50 \\
\hline \multicolumn{3}{|l|}{ Not married } \\
\hline \multicolumn{3}{|l|}{ College enrollment } \\
\hline Full-time enrollment & 13 & 13 \\
\hline Part-time enrollment & 5 & 5 \\
\hline Not enrolled & 82 & 82 \\
\hline \multicolumn{3}{|l|}{ Education level } \\
\hline Primary school & 3 & 3 \\
\hline Some high school & 11 & 10 \\
\hline High school diploma & 33 & 33 \\
\hline Some college & 32 & 33 \\
\hline College degree or more & 21 & 21 \\
\hline \multicolumn{3}{|l|}{ Employment } \\
\hline Employed & 72 & 65 \\
\hline Partially employed & 6 & 21 \\
\hline Not employed & 22 & 14 \\
\hline \multicolumn{3}{|l|}{ Household relationship } \\
\hline Reference person & 43 & 47 \\
\hline Child & 22 & 20 \\
\hline Relative & 31 & 29 \\
\hline Nonrelative & 4 & 4 \\
\hline \multicolumn{3}{|l|}{ New reference person } \\
\hline Yes & 3 & 3 \\
\hline No & 97 & 97 \\
\hline \multicolumn{3}{|l|}{ Homeownership } \\
\hline Homeowner & 59 & 56 \\
\hline Not a homeowner & 31 & 44 \\
\hline \multicolumn{3}{|l|}{ Geographic region } \\
\hline Northeast & 18 & 18 \\
\hline West & 22 & 22 \\
\hline North Central & 25 & 25 \\
\hline South & 35 & 35 \\
\hline Monthly earned income & $\$ 1,695(\$ 2,278)$ & $\$ 2,194(\$ 2,644)$ \\
\hline Age (yr) & $31.889(5.600)$ & $29.760(6.626)$ \\
\hline
\end{tabular}

NOTE: The sample characteristics in this table are drawn from reference month data ( $n=311,446$ person-month observations; $n=30,601$ individuals) and topical module data ( $n=36,415$ individuals). Means and standard deviations (SDs; shown in parentheses) are reported for continuous variables and percentages are reported for categorical variables. SOURCE: Unweighted data from the 1996 SIPP. 


\section{Table 2}

\section{Savings Account, Asset Diversification, and Accumulation Characteristics}

\begin{tabular}{lcc} 
Covariates & $\begin{array}{c}\text { Reference month sample } \\
(\boldsymbol{n}=30,601) \\
\text { Mean (SD)/percent }\end{array}$ & $\begin{array}{c}\text { Topical module sample } \\
(\boldsymbol{n}=36,415) \\
\text { Mean }(\mathrm{SD}) / \text { percent }\end{array}$ \\
\hline $\begin{array}{l}\text { Percentage of savings account and financial } \\
\text { products that comprise a diverse portfolio* } \\
\text { Savings account }\end{array}$ & 43 & 46 \\
\hline Checking account & 24 & 24 \\
\hline CD account & 5 & 5 \\
Money market account & 5 & 5 \\
\hline Savings bond account & 11 & 11 \\
\hline Stock account & 15 & 15 \\
Retirement account & 24 & 25 \\
Value of accumulated liquid assets & & \\
& - & $\$ 6,328$ \\
\end{tabular}

NOTE: The characteristics reported in this table are drawn from the reference month data $(n=311,446$ person-month observations; $n=30,601$ individuals) and topical module data ( $n=36,415$ individuals). Percentages are reported for categorical variables and medians and SDs (shown in parentheses) are reported for continuous variables. *Percentages for savings account and asset diversification strategies are presented for young adults who ever reported owning these account types during the course of the panel using monthly level information. ${ }^{+}$Accumulated liquid assets are presented for young adults based on annual-level information. The accumulated mean value of liquid assets is reported only for young adults who held liquid assets greater than $\$ 0$ and after the value was winsorized.

SOURCE: Unweighted data from the 1996 SIPP.

young adults had a savings account. Among those who accumulated liquid assets, the mean value totaled $\$ 6,328$ (standard deviation $[S D]=\$ 79,498$ ). ${ }^{3}$ Samples from reference month and topical module data were similar on all characteristics; however, young adults from the topical module earned an average of $\$ 500$ more per month. See Tables 1 and 2 for additional sample characteristics.

\section{Measures}

The main analyses examined savings account acquisition, a diverse asset portfolio, and accumulation of liquid assets as outcome variables.

Savings account acquisition. Account ownership by young adults was tracked to determine whether or not, and when, they acquired a savings account (SIPP category EAST2B). This measure was used to model the acquisition of a savings account over the course of the panel. This tracking used quarterly histories and occurred retrospectively over one previous calendar year. For instance, a young adult who originally said he or she did not own a savings account during one quarter and then said yes during the next quarter was considered to have acquired a savings account. Thus, this dependent variable measured young adults' "no-to-yes" change in account ownership compared with those who consistently reported owning a savings 


\section{Friedline, Johnson, Hughes}

account, closing their account, or not acquiring a savings account (savings account closure "yes-to-no"; savings account acquisition "no-to-yes"; savings account ownership "yes-yes"; no savings account ownership "no-no"). Approximately 43 percent of young adults consistently had a savings account and 52 percent consistently did not have a savings account. About 3 percent of young adults acquired an account between quarters and 2 percent closed their account. Acquisition and closure were the most commonly reported savings account transitions. We were also interested in other variations of account acquisition and closure; however, fewer than 1 percent of young adults made multiple transitions throughout the panel. Only one young adult reported vacillating between acquisition and closure at every time point.

Diverse asset portfolio. Aside from a savings account, young adults reported whether they owned other types of financial products that represented additional strategies for asset diversification (yes; no). These included checking (EAST2A), CDs (EAST2D), savings bond (EAST1A, EAST3C), money market (EAST2C), stock (EAST3B, EAST3A), and retirement accounts (EAST1B, EAST1C). Ownership of these financial products was reported quarterly and occurred retrospectively over one previous calendar year. Twenty-four percent of young adults owned checking accounts, 5 percent owned CDs, 11 percent owned savings bonds, 5 percent owned money market accounts, 15 percent owned stock accounts, and 24 percent owned retirement accounts. The asset diversity of portfolios of young adults was explored descriptively rather than as outcomes in prediction models given that (i) the acquisition of a savings account was found to precede or coincide with other financial products that comprised the portfolio and (ii) the acquisition of a savings account was a dominant predictor in preliminary models.

Liquid assets. Young adults were asked to sum the value of liquid assets held in interestearning accounts, including savings and checking accounts, CDs, and money market accounts (TIAITA). Young adults also reported amounts held in bond (TALSBV), stock (ESMIV), and retirement (TALRB, TALTB, TALKB) accounts. These amounts were available from topical modules in waves $3,6,9$, and 12 of the 1996 SIPP and were summed to create a measure of combined liquid assets.

Liquid assets - an outcome variable whose value had the potential to cross or include $\$ 0-$ was winsorized at the 99th percentile to censor extreme values (Cox, 2006) and transformed using the inverse hyperbolic sine (IHS; Friedline, Masa, and Chowa, 2015; Pence, 2006). The IHS transformation has been found to more accurately adjust for skewness in distribution of wealth variables compared with other transformations (Pence, 2006). After the analyses, the IHS-transformed outcome variables were back transformed into real dollars using predicted values that accounted for control variables in the models.

The following 11 variables were included as controls in the analyses:

- age,

- gender (female; male),

- race (nonwhite; Asian; white),

- marital status (married; not married),

- college enrollment (not enrolled; enrolled part-time; enrolled full-time), 
- education level (primary school; partial high school; high school diploma; some college; college degree or more),

- employment (not employed; partially employed; employed),

- quarterly earned income,

- household relationship ([reference person; child; relative; nonrelative] and [new reference person; not a new reference person]),

- homeownership ([owned; rented or occupied] and [owned; purchased; sold; not a homeowner]), and

- geographic region (South; North Central; West; Northeast).

Savings account ownership and owning financial products within a diverse asset portfolio (yes; no) were also used as controls in models predicting liquid assets. Descriptions of these control variables are provided in Appendix A.

Control variables were constructed using information from the preceding months leading up to the fourth reference month in the quarter and averaging across the months. Thus, control variables were coded at the quarterly level for analyses. The quarterly measurements could be used to predict savings account acquisition or measure a diverse asset portfolio given that all were on the same quarterly scale. However, the liquid assets variable was measured at the annual level and the control variables (measured quarterly) needed to be compressed to the same annual time scale as the asset accumulation outcomes. To do so, the control variables were recoded to examine changes between quarters across the year preceding liquid asset accumulation. This meant that a young adult could report not owning a home in the first two quarters and purchasing a home in the third quarter, changing from not owning a home to having purchased a home over the course of the year.

\section{Analysis Plan}

The analysis plan leveraged the quarterly and longitudinal variation in savings account acquisition by young adults to measure associations with a diverse asset portfolio, including ownership of diverse financial products and the accumulation of liquid assets. Three analytic techniques were used. Multinomial logit regression was used to predict account acquisition, and multilevel and censored tobit regressions with individual random effects were used to predict the accumulated liquid assets of young adults. The multinomial logit regression was accomplished using Stata (StataCorp., 2011) and the multilevel and tobit regressions with random effects were accomplished using $\mathrm{R}$ (R Core Team, 2014).

Multinomial logit regression was used to compare quarterly changes in savings account ownership, acquisition, and closure with no savings account ownership after controlling for relevant factors. This technique was ideal because it allowed comparison of multiple account types. Robust standard errors (SEs) and individual clustering were used in the multinomial models to predict savings account acquisition (Hosmer and Lemeshow, 2000). Control variables measured at the quarterly level were included in the model and lagged by one quarter. This meant the previous quarter was used to predict acquisition in the quarter in which the savings account was measured. 
Multilevel (hierarchical linear) modeling was used as the primary analytic technique to predict liquid assets given the technique's ability to (i) model random effects accounting for unobserved individual heterogeneity and (ii) control for categorical and continuous variables (Raudenbush and Bryk, 2002). In other words, multilevel modeling was used to account for differences among individuals that existed within the data. The nonlinear mixed effects (nlme) add-on package in $\mathrm{R}$ was used for multilevel modeling (Pinheiro et al., 2009) and robust SEs were produced using a Huber-White correction (Huber, 1967; Maas and Hox, 2004; Raudenbush and Bryk, 2002; White, 1982).

As a comparison with the multilevel modeling, tobit regression analysis with individual random effects was used to predict liquid assets (Honoré, Kyriazidou, and Powell, 2000, and Tobin, 1958). ${ }^{4}$ Tobit regression was used given that the liquid assets variable was left-censored, meaning that many values were recorded as $\$ 0$. This analytic technique depicted these censored outcomes as information from a continuously distributed latent variable and avoided introducing bias in the estimates by omitting this information (Angrist, 2001). In other words, censored tobit regression attempted to minimize the $\$ 0$ liquid asset amounts from young adults who did not have savings or other accounts or any liquid assets. ${ }^{5}$ The censReg (censored regression) add-on package in $\mathrm{R}$ was used to conduct the censored tobit regressions with random effects (Henningsen, 2010, 2013) and was dependent on the maxLik package in R for producing maximum likelihood (ML) estimates (Henningsen and Toomet, 2011) (Table 3). The results reported in the text focus on the multilevel model with individual random effects, as results from the censored tobit regression were provided as a type of sensitivity analysis.

\section{RESULTS}

\section{Acquiring a Savings Account}

Small percentages of young adults acquired or closed accounts between quarters. About 3 percent of young adults acquired an account and 2 percent closed an account. The predominant behaviors with regard to a savings account were consistently having owned or never having owned a savings account, with respective percentages of 43 and 52. Figure 1 graphs young adults' savings account ownership, acquisition, and closure by age. However, Figure 1 also shows the likelihood of owning a savings account increased with age, which suggests that while young adults were not sensitive to acquisition between quarters, they increasingly acquired accounts through their mid- to late 20s before the percentage leveled off in their 30s. ${ }^{6}$

Multinomial logit models predicted young adults' acquisition of a savings account between quarters, comparing savings account ownership ("yes-yes"), acquisition ("no-to-yes"), and closure ("yes-to-no") with no savings account ownership ("no-no"; see Table 2). The models of primary interest compared acquisition and closure with no savings account ownership (Models 2 and 3).

Savings Account Ownership (Model 1). Females were more likely than males to own a savings account. By race, young adults who were nonwhite or Asian were both less likely to own accounts compared with whites. Young adults were also more likely to own accounts 
Friedline, Johnson, Hughes

\section{Table 3}

\section{Multinomial Logit Regression Models of Quarterly Change in Savings Ownership, Acquisition, and Closure Compared with No Savings Account Ownership ${ }^{\dagger}$}

\begin{tabular}{|c|c|c|c|c|c|c|}
\hline \multirow[b]{3}{*}{ Covariates } & \multicolumn{2}{|c|}{ Model 1} & \multicolumn{2}{|c|}{ Model 2} & \multicolumn{2}{|c|}{ Model 3} \\
\hline & \multicolumn{2}{|c|}{$\begin{array}{l}\text { No account ownership } \\
\text { vs. account ownership }\end{array}$} & \multicolumn{2}{|c|}{$\begin{array}{l}\text { No account ownership } \\
\text { vs. account acquisition }\end{array}$} & \multicolumn{2}{|c|}{$\begin{array}{l}\text { No account ownership } \\
\text { vs. account closure }\end{array}$} \\
\hline & $\beta$ & SE & $\beta$ & SE & $\beta$ & SE \\
\hline \multicolumn{7}{|l|}{ Sex: Male } \\
\hline Female & $0.101^{* * *}$ & $(0.008)$ & 0.005 & $(0.022)$ & 0.022 & $(0.022)$ \\
\hline \multicolumn{7}{|l|}{ Race: White } \\
\hline Nonwhite & $-0.925^{* * *}$ & $(0.013)$ & $-0.349^{* * *}$ & $(0.033)$ & $-0.404^{* * *}$ & $(0.033)$ \\
\hline Asian & $-0.133^{* * *}$ & $(0.021)$ & $0.132^{* *}$ & $(0.054)$ & 0.079 & $(0.055)$ \\
\hline \multicolumn{7}{|l|}{ Marital status: Not married } \\
\hline Married & 0.010 & $(0.009)$ & 0.009 & $(0.024)$ & $0.064^{* * *}$ & $(0.024)$ \\
\hline \multicolumn{7}{|l|}{ School enrollment: Full-time } \\
\hline Enrolled part-time & 0.006 & $(0.021)$ & -0.015 & $(0.059)$ & 0.020 & $(0.060)$ \\
\hline Not enrolled & -0.005 & $(0.014)$ & -0.022 & $(0.037)$ & 0.015 & $(0.038)$ \\
\hline \multicolumn{7}{|l|}{ Education level: Primary school } \\
\hline Some high school & -0.019 & $(0.025)$ & -0.048 & $(0.068)$ & -0.000 & $(0.070)$ \\
\hline High school diploma & -0.015 & $(0.023)$ & -0.020 & $(0.062)$ & 0.013 & $(0.064)$ \\
\hline Some college & -0.022 & $(0.023)$ & -0.081 & $(0.063)$ & 0.013 & $(0.065)$ \\
\hline College degree or more & -0.017 & $(0.024)$ & -0.071 & $(0.066)$ & -0.025 & $(0.067)$ \\
\hline \multicolumn{7}{|l|}{ Employment status: Employed } \\
\hline Partially employed & 0.025 & $(0.018)$ & 0.011 & $(0.048)$ & 0.064 & $(0.050)$ \\
\hline Not employed & 0.026 & $(0.027)$ & $-0.155^{* *}$ & $(0.071)$ & $0.187^{* *}$ & $(0.077)$ \\
\hline \multicolumn{7}{|l|}{ New reference person: No } \\
\hline Yes & 0.011 & $(0.009)$ & -0.005 & $(0.023)$ & 0.005 & $(0.023)$ \\
\hline \multicolumn{7}{|c|}{ Homeownership: Not a homeowner } \\
\hline Homeowner & $0.138^{* * *}$ & $(0.025)$ & $-0.663^{* * *}$ & $(0.046)$ & $-0.571^{* * *}$ & $(0.049)$ \\
\hline \multicolumn{7}{|l|}{ Geographic region: Northeast } \\
\hline West & $-0.277^{* * *}$ & $(0.013)$ & -0.047 & $(0.034)$ & -0.008 & $(0.035)$ \\
\hline North Central & 0.019 & $(0.012)$ & -0.044 & $(0.034)$ & 0.045 & $(0.035)$ \\
\hline South & $-0.419^{* * *}$ & $(0.012)$ & $-0.287^{* * *}$ & $(0.032)$ & $-0.204^{* * *}$ & $(0.033)$ \\
\hline Quarterly mean income spline 1 & -12.464 & $(6.451)$ & 10.960 & $(19.520)$ & 90.076 & $(73.601)$ \\
\hline Quarterly mean income spline 2 & -11.984 & $(6.428)$ & 11.093 & $(19.463)$ & 90.891 & (73.507) \\
\hline Quarterly mean income spline 3 & -12.048 & $(6.434)$ & 10.892 & $(19.479)$ & 90.958 & (73.537) \\
\hline Quarterly mean income spline 4 & -11.962 & $(6.386)$ & 11.233 & $(19.350)$ & 90.491 & (73.264) \\
\hline Quarterly mean income spline 5 & -13.322 & $(7.128)$ & 10.924 & $(21.381)$ & 98.168 & (78.896) \\
\hline Age spline 1 & $1.130^{* * *}$ & $(0.375)$ & $-4.700 * * *$ & $(1.040)$ & $-2.648^{* *}$ & $(1.036)$ \\
\hline Age spline 2 & $-1.948^{* * *}$ & $(0.205)$ & $-1.507^{* *}$ & $(0.595)$ & -0.261 & (0.599) \\
\hline Age spline 3 & $-0.523^{* *}$ & $(0.231)$ & $-1.304^{* *}$ & $(0.665)$ & -0.232 & $(0.672)$ \\
\hline Age spline 4 & -0.228 & $(0.199)$ & -1.314 & $(0.580)$ & -0.041 & $(0.586)$ \\
\hline Age spline 5 & -0.079 & $(0.259)$ & $-1.671^{* *}$ & $(0.751)$ & -0.195 & $(0.756)$ \\
\hline \multirow[t]{2}{*}{ Constant } & $12.638^{* * *}$ & & -12.089 & & -93.451 & \\
\hline & $-0.277^{* * *}$ & & -0.047 & & -0.008 & \\
\hline Log pseudo-likelihood & $-248,450.850$ & & & & & \\
\hline Wald chi-square & $18,224.530$ & & & & & \\
\hline Degrees of freedom & 81 & & & & & \\
\hline$N=$ Person-month observations & 280,845 & & & & & \\
\hline$N=$ Individual clusters & 29,585 & & & & & \\
\hline
\end{tabular}

NOTE: Listwise deletion of missing data was used and reduced the original sample of 311,446 person-month observations to 280,845 and 30,601 individuals to 29,585 , respective reductions of 10 percent and 3 percent. Robust SEs, clustered by individual, are reported in parentheses. ${ }^{\dagger} \mathrm{No}$ savings account ownership "no-no"; savings account ownership "yes-yes"; savings account acquisition "no-to-yes"; savings account closure "yesto-no." $\beta$, regression coefficient; $S E$, robust SE. ** and *** indicate significance at the 5 percent and 1 percent levels, respectively.

SOURCE: Unweighted data from the 1996 SIPP. 


\section{Figure 1}

\section{Percentage of Savings Account Ownership, Acquisition, and Closure by Age of Young Adults}

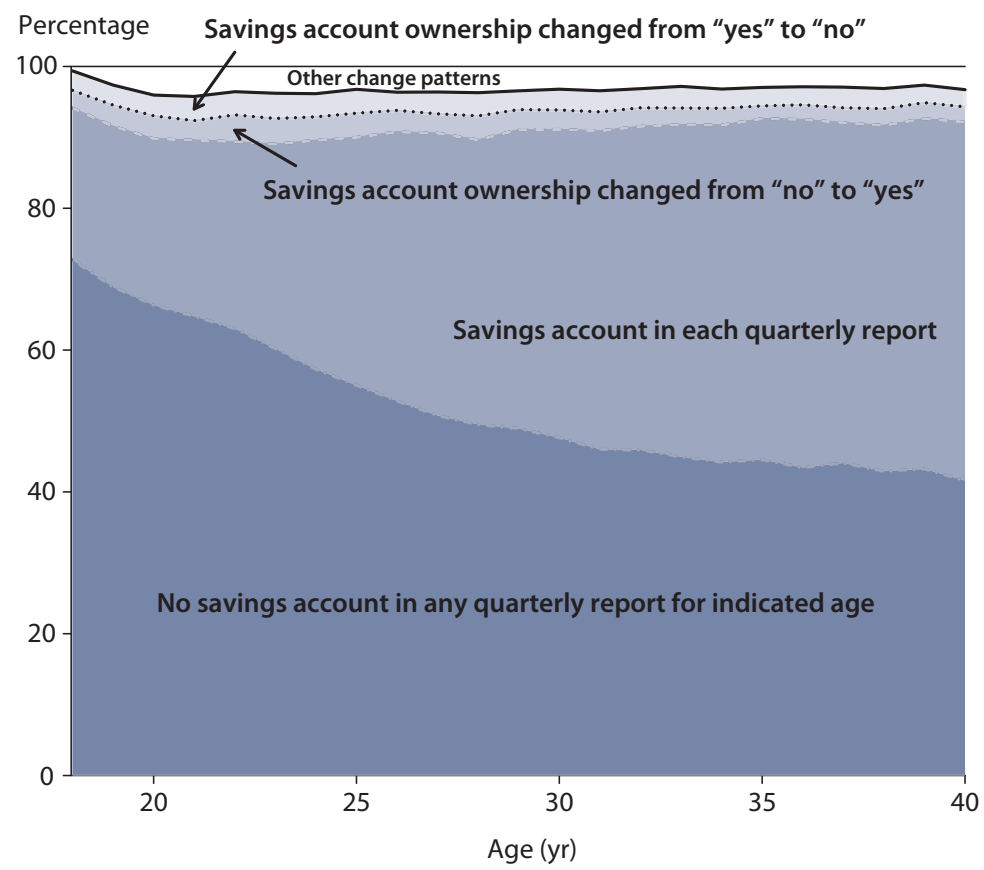

NOTE: This figure was produced with person-month and individual observations ( $n=311,446$ person-month observations; $n=30,601$ individuals).

SOURCE: Unweighted data from the 1996 SIPP.

compared with not owning a savings account when they owned their own homes. Living in the West and South was negatively related to account ownership compared with living in the Northeast. Splines for age indicated that young adults' savings account ownership declined as they grew older, with the exception that adults in the youngest age spline were more likely to own an account.

Savings Account Acquisition (Model 2). Asian young adults were more likely to acquire a savings account than their white counterparts, and nonwhite young adults were less likely to acquire an account. Being unemployed and living in the South were negatively related to the acquisition of a savings account. Young adults were less likely to acquire an account if they were homeowners. Given that young adults were more likely to own an account initially if they were a homeowner (see Model 1), this negative relationship was not surprising.

Savings Account Closure (Model 3). Nonwhite young adults were less likely to close a savings account compared with whites, although they were also less likely to own accounts initially (Model 1). Those who were unemployed were more likely to close an account. Young adults who owned a home were also less likely to close a savings account compared with nonhomeowners. Young adults who were married were more likely to close an account than to not own one. 
In sum, young adults' race, employment status, homeownership, geographic region, and age were consistently related to account ownership, acquisition, and closure across the models. The findings from the multinomial logit models can be interpreted as follows. Given that nonwhite young adults were less likely to own an account initially compared with whites, they were also less likely to exhibit quarterly changes in account acquisition and closure. However, even though Asians were less likely to own an account compared with whites, they were more likely to acquire one between quarters. There were no differences in ownership and acquisition based on marital status; however, those who were married were more likely to close an account-an observation that was perhaps an artifact of joint account-holding behavior between marital partners. There was no difference in account ownership between young adults who were employed versus unemployed, but those who were unemployed were less likely to acquire an account between quarters and more likely to close an account. This suggests employment status may have played a role in facilitating the use of a savings account. Homeowners were more likely to own an account initially, which perhaps explains why they were also less likely to acquire or close accounts between quarters. Notably, education level and quarterly earned income were not significant in any of the models.

\section{Diversifying Asset Portfolios}

Compared with the percentage of young adults who owned and acquired a savings account, far fewer owned a diverse portfolio. As mentioned earlier, 24 percent of young adults owned checking accounts, 5 percent owned CDs, 5 percent owned money market accounts, 11 percent owned savings bond accounts, 15 percent owned stock accounts, and 24 percent owned retirement accounts. However, if the acquisition of a savings account serves as a gateway through which young adults can diversify their asset portfolios, savings accounts should consistently precede or occur simultaneously with the ownership or acquisition of these financial products. Figures 2 through 4 display young adults' portfolios as they relate to a savings account.

In most cases, young adults owned a savings account at or before the acquisition of checking, $\mathrm{CD}$, money market, savings bond, stock, and retirement accounts (see Figures 2 and 3). Figure 2 presents the percentage of young adults with a savings account who also owned other financial products. Figure 3 presents the percentage of acquired financial products that were preceded by or coincided with owning a savings account, which required determining the point in the 1996 SIPP at which young adults first acquired these products and identifying if they owned a savings account at that time or in any preceding month. For instance, 44 percent of young adults with a savings account also owned a checking account (see Figure 2), and for most young adults the acquisition of a checking account was preceded by or coincided with owning a savings account (23 percent; see Figure 3 ). Forty-two percent of young adults with a savings account also owned a retirement account (see Figure 2), and for most young adults the acquisition of a retirement account was preceded by or coincided with a savings account (21 percent; see Figure 3). Far fewer financial products were owned or acquired in the absence of a savings account.

Young adults also acquired savings accounts in combination with other financial products as they grew older (see Figure 4). The most common combinations were savings accounts 
Friedline, Johnson, Hughes

\section{Figure 2}

Percentage of Young Adults with a Savings Account Who Also Owned Other Financial Products
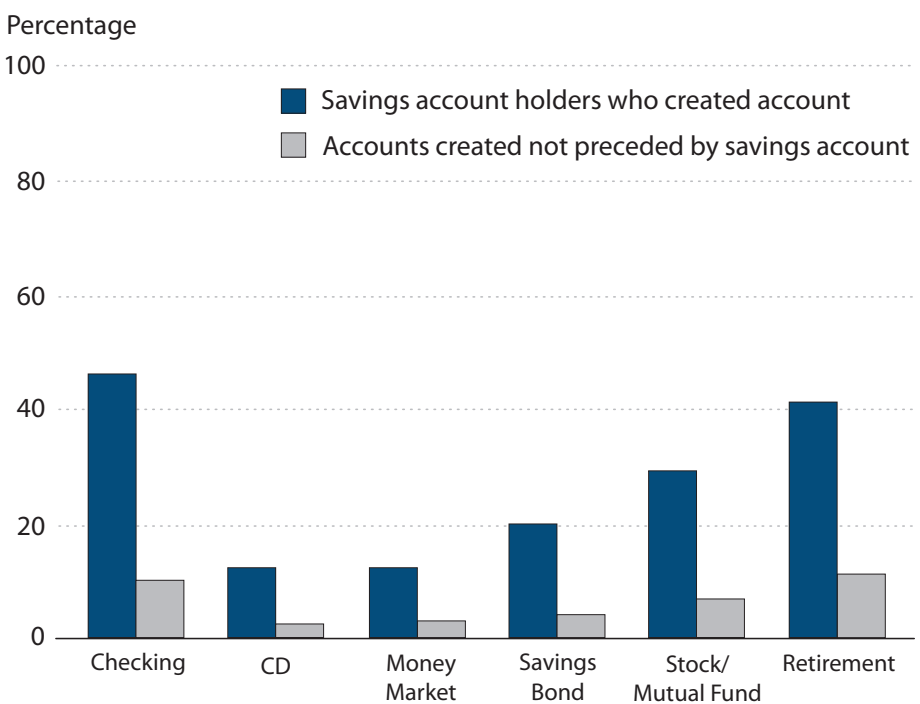

\section{Figure 3}

Percentage of Young Adults Who Acquired Financial Products Coincident With or Preceded by a Savings Account

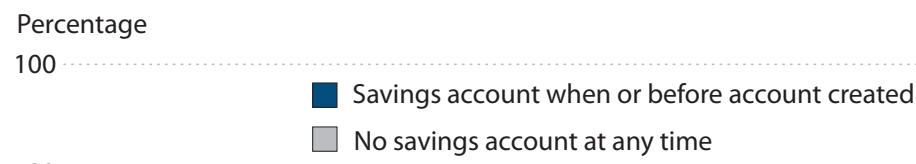

60

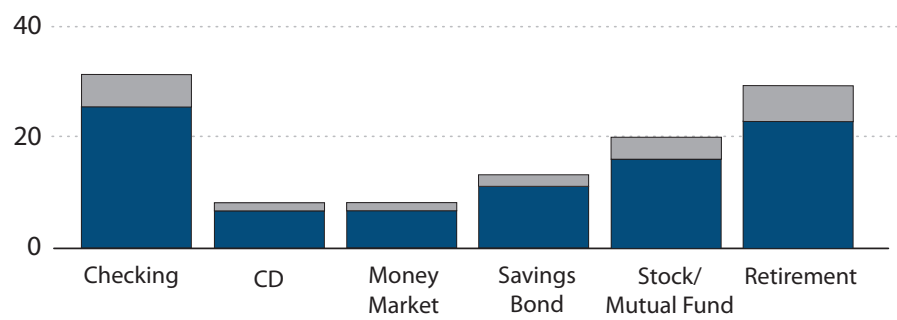

NOTE: Figures 2 and 3 were produced with person-month and individual observations ( $n=311,446$ person-month observations; $n=30,601$ individuals).

SOURCE: Unweighted data from the 1996 SIPP. 


\section{Figure 4}

\section{Percentage of Savings Account Ownership by Young Adults Combined with Ownership of Other Financial Products by Age}

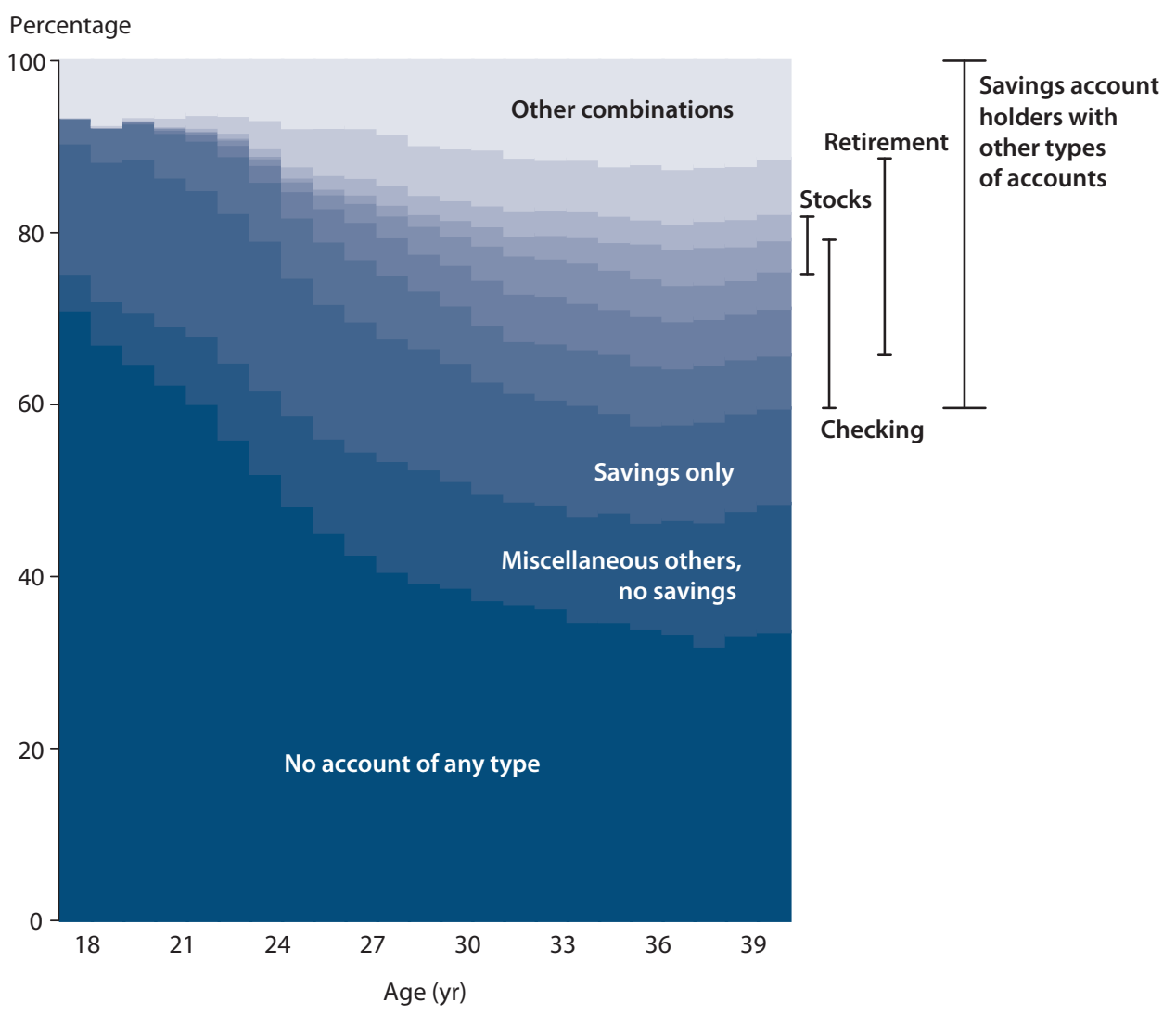

NOTE: This figure was produced with person-month and individual observations ( $n=311,446$ person-month observations; $n=30,601$ individuals).

SOURCE: Unweighted data from the 1996 SIPP.

plus checking, stock, and/or retirement accounts. Similar to the scenario in Figure 1, young adults may have increasingly acquired accounts and diversified their asset portfolios through their mid- to late 20 s before the trend leveled off in their $30 \mathrm{~s}$.

In sum, young adults who owned a savings account appeared to own other financial products more often. Furthermore, savings account ownership consistently preceded or coincided with the acquisition of other financial products. 


\section{Accumulating Liquid Assets}

Information on the accumulated liquid assets of young adults was provided from annual topical modules and analyzed using multilevel and censored tobit regression modeling with individual random effects (see Table 4, Models 4 through 6). Random effects accounted for unobserved individual heterogeneity. The intraclass correlation (Raudenbush and Bryk, 2002) defined as the between-individual variance divided by the total variance of liquid assetsranged from 0.305 (Model 5) to 0.540 (Model 6), indicating that significant differences in the individual characteristics of young adults explained between 30 percent and 54 percent of the variability in liquid assets. The results reported below focus on the multilevel analyses from Models 4 and 5. The relationships between financial products and liquid assets are reported first before a discussion of the relationships between control variables and liquid assets.

As a first step, the financial products representing a diverse portfolio were used to predict liquid assets in Model 4, absent control variables. It was previously determined that a savings account was a gateway to a diverse asset portfolio and almost always coincided with or preceded the acquisition of other types of financial products. As such, the relationships between liquid assets and checking, stock, and retirement accounts can be interpreted as the added contribution of a diverse portfolio over and above a savings account. As expected, young adults with no account of any kind accumulated significantly fewer liquid assets, whereas those with other account types accumulated significantly more. In particular, the relationships were strongest between stock and retirement accounts and liquid assets, although the combination of these accounts was negatively related to liquid assets.

While some variation in the size or strength of the estimates exists between Models 4 and 5, the direction of the relationships remained fairly consistent once control variables were added. With controls, savings and stock accounts had the strongest relationships with liquid assets based on regression coefficients. However, using predicted values (Table 5), a savings account contributed $\$ 49.68$ and stocks contributed $\$ 329.50$ to accumulated liquid assets. In terms of dollar values, the combination of stock and retirement accounts contributed the most, $\$ 5,283.05$, to liquid asset accumulation by young adults. Results also indicated that retirement accounts and the combination of stock and retirement accounts contributed negatively to young adults' liquid assets.

Given that the acquisition of financial products could be determined in part by age and income, interaction effects were incorporated. There were significant, positive interactions between the age of young adults and their retirement and combined stock and retirement accounts for predicting liquid assets. Predicted values based on these interactions indicated that as young adults ascended age quintiles, their contributions to liquid assets by combined stock and retirement accounts ranged from $\$ 4,900.80$ to $\$ 12,385.20$ (Table 6). Also consistent with the interaction terms between age and financial products from Model 5, the amounts contributed to liquid assets by savings, checking, and stocks declined across the 25th, 50th, and 75 th age quintiles.

There was a significant, positive interaction between ownership of stock and retirement accounts and quarterly mean income; however, the interaction between the combined accounts and liquid assets was negative. Predicted values indicated that the contributions to liquid 


\section{Table 4}

\section{Models Predicting Liquid Assets (IHS-Transformed; $N=\mathbf{3 6 , 4 1 5}$ )}

\begin{tabular}{|c|c|c|c|c|c|c|}
\hline \multirow[b]{3}{*}{ Covariates } & \multicolumn{2}{|c|}{ Model 4} & \multicolumn{2}{|c|}{ Model 5} & \multicolumn{2}{|c|}{ Model 6} \\
\hline & \multicolumn{2}{|c|}{$\begin{array}{l}\text { Multilevel model with } \\
\text { individual random effects }\end{array}$} & \multicolumn{2}{|c|}{$\begin{array}{l}\text { Multilevel model with } \\
\text { individual random effects }\end{array}$} & \multicolumn{2}{|c|}{$\begin{array}{l}\text { Multilevel model with } \\
\text { individual random effects }\end{array}$} \\
\hline & $\beta$ & SE & $\beta$ & SE & $\beta$ & SE \\
\hline \multicolumn{7}{|c|}{ Financial products from a diverse asset portfolio } \\
\hline No account of any kind & $-3.479 * * *$ & $(0.035)$ & $-3.382^{* * *}$ & $(0.035)$ & $-8.852^{* * *}$ & $(0.074)$ \\
\hline Savings account & $0.272^{* * *}$ & $(0.030)$ & $2.956^{* * *}$ & $(0.098)$ & $2.274^{* * *}$ & $(0.185)$ \\
\hline Checking account & $0.093^{* * *}$ & $(0.026)$ & $0.517^{* * *}$ & $(0.122)$ & $0.499^{* *}$ & $(0.193)$ \\
\hline Stock/mutual fund account & $2.102^{* * *}$ & $(0.043)$ & $3.178^{* * *}$ & $(0.188)$ & $2.259^{* * *}$ & $(0.293)$ \\
\hline Retirement account & $4.576^{* * *}$ & $(0.031)$ & $-0.808^{* * *}$ & $(0.161)$ & $-1.225^{* * *}$ & $(0.248)$ \\
\hline Stock and retirement accounts & $-1.094^{* * *}$ & $(0.057)$ & $-1.859^{* * *}$ & $(0.313)$ & $-1.043^{* *}$ & $(0.460)$ \\
\hline Age & & & $0.023^{* * *}$ & $(0.002)$ & $-0.013^{* *}$ & $(0.006)$ \\
\hline \multicolumn{7}{|l|}{ Sex: Male } \\
\hline Female & & & $-0.082^{* * *}$ & $(0.022)$ & $-0.230^{* * *}$ & $(0.045)$ \\
\hline \multicolumn{7}{|l|}{ Race: White } \\
\hline Nonwhite & & & $-0.266^{* * *}$ & $(0.031)$ & $-0.409^{* * *}$ & $(0.073)$ \\
\hline Asian & & & -0.037 & $(0.055)$ & -0.011 & $(0.112)$ \\
\hline \multicolumn{7}{|l|}{ Marital status: Not married } \\
\hline Married & & & $-1.437^{* * *}$ & $(0.022)$ & $-3.008^{* * *}$ & $(0.045)$ \\
\hline \multicolumn{7}{|l|}{ College enrollment: Not enrolled } \\
\hline Part-time enrollment & & & $0.140 * * *$ & $(0.036)$ & $0.248^{* * *}$ & $(0.061)$ \\
\hline Full-time enrollment & & & $0.319^{* * *}$ & $(0.030)$ & $0.660^{* * *}$ & $(0.059)$ \\
\hline \multicolumn{7}{|l|}{ Education level: Primary school } \\
\hline Some high school & & & -0.113 & $(0.064)$ & $0.568^{* * *}$ & $(0.209)$ \\
\hline High school diploma & & & -0.067 & $(0.060)$ & $0.987^{* * *}$ & $(0.197)$ \\
\hline Some college & & & 0.067 & $(0.061)$ & $1.289 * * *$ & $(0.197)$ \\
\hline College degree or more & & & $0.476^{* * *}$ & $(0.064)$ & $1.890^{* * *}$ & $(0.199)$ \\
\hline \multicolumn{7}{|l|}{ Employment status: Not employed } \\
\hline Partially employed & & & $0.107^{* * *}$ & $(0.030)$ & $0.289^{* * *}$ & $(0.067)$ \\
\hline Employed & & & $0.206^{* * *}$ & $(0.032)$ & $0.493^{* * *}$ & $(0.070)$ \\
\hline Quarterly mean income/1,000 & & & $0.039 * * *$ & $(0.013)$ & $0.238^{* * *}$ & $(0.028)$ \\
\hline \multicolumn{7}{|l|}{ New reference person: False } \\
\hline True & & & $0.113^{* *}$ & $(0.044)$ & $0.170^{* *}$ & $(0.079)$ \\
\hline \multicolumn{7}{|c|}{ Change in homeownership: Not a homeowner } \\
\hline Owned & & & $0.150^{* * *}$ & $(0.021)$ & $0.407^{* * *}$ & $(0.043)$ \\
\hline Purchased & & & 0.022 & $(0.039)$ & $0.167^{* *}$ & $(0.068)$ \\
\hline Sold & & & 0.032 & $(0.046)$ & 0.084 & $(0.085)$ \\
\hline \multicolumn{7}{|l|}{ Geographic region: Northeast } \\
\hline West & & & $-0.214^{* * *}$ & $(0.032)$ & $-0.430^{* * *}$ & $(0.066)$ \\
\hline North Central & & & $-0.141^{* * *}$ & $(0.032)$ & $-0.262^{* * *}$ & $(0.063)$ \\
\hline South & & & $-0.218^{* * *}$ & $(0.030)$ & $-0.465^{* * *}$ & $(0.061)$ \\
\hline Interactions of financial products $\mathrm{w}$ & & & & & & \\
\hline Savings account & & & $-0.091^{* * *}$ & $(0.003)$ & $-0.056^{* * *}$ & $(0.006)$ \\
\hline Checking account & & & $-0.015^{* * *}$ & $(0.004)$ & -0.010 & $(0.006)$ \\
\hline Stock account & & & $-0.033^{* * *}$ & $(0.006)$ & $-0.021^{* *}$ & $(0.010)$ \\
\hline Retirement account & & & $0.147^{* * *}$ & $(0.005)$ & $0.197^{* * *}$ & $(0.008)$ \\
\hline Stock and retirement accounts & & & $0.032^{* * *}$ & $(0.010)$ & $-0.021^{* * *}$ & $(0.014)$ \\
\hline Interactions of financial products $\mathrm{W}$ & arterly mean & 1,000 & & & & \\
\hline Savings account & & & $0.076^{* * *}$ & $(0.014)$ & -0.044 & $(0.023)$ \\
\hline Checking account & & & $0.057^{* * *}$ & $(0.014)$ & 0.024 & $(0.022)$ \\
\hline Stock account & & & $0.048^{* *}$ & $(0.024)$ & $-0.082^{* *}$ & $(0.037)$ \\
\hline Retirement account & & & $0.315^{* * *}$ & $(0.019)$ & $0.163^{* * *}$ & $(0.029)$ \\
\hline Stock and retirement accounts & & & $-0.231^{* * *}$ & $(0.031)$ & -0.077 & $(0.046)$ \\
\hline Constant & $3.686^{* * *}$ & $(0.033)$ & $1.915^{* * *}$ & $(0.103)$ & $0.580^{* *}$ & $(0.285)$ \\
\hline Random effects $(\sigma)$ & & & & & & \\
\hline Residual & 2.15 & & 2.13 & & 2.13 & \\
\hline Individual effect & 1.69 & & 1.41 & & 1.41 & \\
\hline Intraclass correlation & 0.381 & & 0.305 & & 0.540 & \\
\hline
\end{tabular}

NOTE: $\beta$, regression coefficient; $S E$, robust SE. ${ }^{* *}$ and ${ }^{* * *}$ indicate significance at the 5 percent and 1 percent levels, respectively. SOURCE: Unweighted data from the 1996 SIPP. 


\section{Table 5}

Predicted Values of Contributions of a Diverse Asset Portfolio to Accumulated Liquid Assets (IHS-Transformed; $N=36,415)$

\begin{tabular}{|c|c|c|}
\hline \multirow[b]{2}{*}{ Covariates } & \multirow{2}{*}{$\begin{array}{c}\text { Model } 4 \\
\text { Multilevel model with } \\
\text { individual random effects } \\
\text { (financial-products-only model) }\end{array}$} & \multirow{2}{*}{$\begin{array}{c}\text { Model } 5 \\
\begin{array}{c}\text { Multilevel model with } \\
\text { individual random effects } \\
\text { (full model) }\end{array}\end{array}$} \\
\hline & & \\
\hline \multicolumn{3}{|c|}{ Financial products from a diverse asset portfolio } \\
\hline No account of any kind (\$) & 0.21 & 0.95 \\
\hline Savings account (\$) & 26.15 & 49.68 \\
\hline Checking account $(\$)$ & 21.86 & 40.34 \\
\hline Stock account $(\$)$ & 163.04 & 329.50 \\
\hline Retirement account (\$) & $1,937.09$ & $1,992.07$ \\
\hline Stock and retirement account (\$) & $5,302.87$ & $5,283.05$ \\
\hline
\end{tabular}

assets made by stock and retirement accounts were sensitive to income (see Table 6). At the 25 th quintile of income, the predicted value of a retirement account was $\$ 1,699.58$; however, at the 75 th quintile, the predicated value was $\$ 3,945.08$. Likewise, the combined stock and retirement accounts at the 25 th income quintile were $\$ 5,650.18$ compared with $\$ 9,151.51$ at the 75 th income quintile.

The relationships between control variables and liquid assets were also examined (see Table 4 and Model 5). As expected, young adults who were older, enrolled in college, had a college degree or more, earned a higher quarterly income, recently became a new head of household, and owned their own homes accumulated significantly more liquid assets than their counterparts. Young adults who were female, nonwhite, married, and lived in geographic regions other than the Northeast accumulated significantly fewer liquid assets.

In sum, the financial products from a diverse portfolio were significantly related to the accumulated liquid assets of young adults. Significant, negative interactions between age and savings, checking, and stock accounts suggested that the effects of these financial products on liquid asset accumulation diminished as young adults grew older. Conversely, as young adults earned more income, the effects of these financial products on liquid asset accumulation increased. Likewise, as young adults grew older and earned more income, the effects increased.

\section{DISCUSSION}

Our research attempted to understand young adults' balance sheets through two avenues with 1996 SIPP data, with particular attention to the acquisition and role of a savings account. The first avenue emphasized the ownership of a diverse asset portfolio with financial products, 
Friedline, Johnson, Hughes

\section{Table 6}

\section{Predicted Values of Contributions of a Diverse Asset Portfolio to Accumulated Liquid Assets by Quintiles of Age and Quarterly Mean Income (IHS-Transformed; $N=36,415$ )}

\begin{tabular}{lrrrrrr} 
& \multicolumn{3}{c}{ Age quintiles } & \multicolumn{3}{c}{ Income quintiles } \\
\cline { 2 - 6 } Covariates & 25th & 50th & 75th & 25th & 50th & 75th \\
\hline Financial products from a diverse asset portfolio & & & & & & \\
\hline$\quad$ No account of any kind (\$) & 0.77 & 0.96 & 1.16 & 0.89 & 0.93 & 0.99 \\
$\quad$ Savings account $(\$)$ & 73.41 & 48.88 & 32.54 & 43.11 & 47.75 & 54.03 \\
\hline Checking account $(\$)$ & 94.09 & 57.27 & 34.85 & 47.28 & 55.07 & 66.20 \\
$\quad$ Stock account $(\$)$ & 854.12 & 465.66 & 253.87 & 390.45 & 451.16 & 537.13 \\
$\quad$ Retirement account $(\$)$ & $1,830.75$ & $2,938.81$ & $4,717.53$ & $1,699.58$ & $2,489.15$ & $3,945.08$ \\
$\quad$ Stock and retirement accounts (\$) & $4,900.80$ & $7,790.85$ & $12,385.20$ & $5,650.18$ & $7,030.04$ & $9,151.51$
\end{tabular}

NOTE: Values expressed in U.S. dollars. Predicted values were calculated by back transforming the IHS transformation of accumulated liquid assets into real dollars.

SOURCE: Unweighted data from the 1996 SIPP.

such as CDs, mutual funds, or other brokerage accounts, while the second considered the accumulated value of liquid assets.

Our first research question focused on factors related to the acquisition, or take-up, of a savings account by young adults. A majority of young adults either owned or did not own a savings account, with far fewer acquiring or closing a savings account over the course of the panel. At least descriptively speaking, these percentages suggested that account ownership may have been "sticky" and guided by inertia-the currently observed behavior was guided in part by the previously observed behavior (Thaler and Sunstein, 2009; for further discussion, see Appendix B). If ownership and maintenance of a savings account by young adults is as constant as these results suggest and previous research confirms (Benartzi and Thaler, 2007; Friedline and Elliott, 2013; Friedline, Elliott, and Chowa, 2013; Madrian and Shea, 2001), then the initial acquisition of a savings account may be important for continued account ownership.

Given the apparent importance of inertia in savings account ownership, we explored factors that predicted the acquisition of a savings account by young adults during the course of the panel. Race, employment status, homeownership, geographic region, and age were among the significant predictors in the multinomial logit model comparing account acquisition with no account ownership. The relationships between these control variables and account acquisition were in the expected directions. For instance, nonwhite young adults were less likely to acquire accounts than white young adults (Friedline and Elliott, 2011), whereas Asians were significantly more likely to do so. While nonwhites were less likely to have a savings account initially, the fact that they were also less likely to acquire a savings account suggests they may experience continued exclusion from financial mainstream institutions, a finding consistent with previous research (Federal Deposit Insurance Corporation [FDIC], 2012, and Shapiro, Meschede, and Osoro, 2013). 


\section{Friedline, Johnson, Hughes}

Unemployed young adults were less likely than those who were employed to acquire an account, suggesting employment may be one path to account acquisition (Rhine and Greene, 2013). One explanation for the link between young adult employment and the acquisition of a savings account may be that employers offer-if not mandate-direct deposit for paychecks. Employment thus may have helped to ensure that young adults acquired accounts, whereas unemployment may have made this acquisition less likely.

Our second research question asked whether ownership or acquisition of a savings account was a gateway to a diverse asset portfolio. Consistently, young adults who owned a savings account appeared to also own other financial products more often, and their savings account ownership preceded or coincided with the acquisition of other financial products. While few young adults had a diverse portfolio-meaning that few young adults owned a savings account in combination with other financial products (see Figure 4; Cooper, 2013, and King and Leape, 1998) — checking, stock, and retirement accounts were among the most commonly acquired products as part of a diverse portfolio. Taken together, it appears that a savings account may be one of the first financial products acquired as young adults ascend the financial hierarchy and may almost be considered a prerequisite for-not simply a gateway to-a diverse asset portfolio (Xiao and Anderson, 1997), which is one measure of a healthy balance sheet (Fabozzi, Gupta, and Markowitz, 2002).

Our third research question explored the extent to which a savings account and a diverse asset portfolio contributed to the value of young adults' accumulated liquid assets. In addition to a savings account, we focused on the financial products most commonly owned by young adults - checking, stock, and retirement accounts. Given that a savings account was almost a prerequisite for the financial products that comprised a diverse portfolio, their relationships to liquid assets were seen as additive. That is, these financial products represented the added effects on liquid assets when combined with a savings account. Indeed, as young adults ascended the financial hierarchy and acquired stock and retirement accounts that represented long-term, higher-level needs, they also accumulated significantly more liquid assets. A savings or checking account alone contributed small amounts-respectively, $\$ 49.68$ and $\$ 40.34$. Initially, it appeared that a retirement account was negatively related to accumulated liquid assets; however, considered in light of increasing quarterly mean income, a retirement account contributed substantially to accumulated liquid assets. A retirement account contributed $\$ 1,699.58$ at the 25 th income quintile and $\$ 3,945.08$ at the 75 th income quintile. When combined with stocks, young adults accumulated $\$ 5,650.18$ at the 25 th income quintile compared with $\$ 9,151.51$ at the 75th income quintile. This suggests that the financial hierarchy that young adults ascend, in addition to helping diversify their portfolios (Xiao and Anderson, 1997; Xiao and Noring, 1994), may contribute to accumulated liquid assets.

\section{Limitations}

Findings from this research should be considered in light of several limitations. The measures included in this research were limited to those available from the 1996 SIPP, and many contextual factors with potential relevance to young adults' balance sheets were not 
incorporated into the analyses. These factors include family history of financial socialization, availability of banks within a community, U.S. economic growth during the 1990s, and the banking mergers and closures during the late 1980s and early 1990s preceding the 1996 SIPP data collection (FDIC, 1997, and Serido et al., 2010). While this research cannot rule out the relationships between these contextual factors and the balance sheets of young adults, measuring the changes in employment, education level, income, or household relationship provided some context. The 1996 SIPP data itself had some complexities, including oversampling of lower-income young adults, resulting in less frequent ownership of a savings account or other diverse financial products and fewer accumulated assets compared with other surveys (Czajka, Jacobson, and Cody, 2003).

In addition, imprecise reporting of retrospective monthly or quarterly information may have resulted in excessive transitions between reference periods (also known as "seam bias"; see Moore et al., 2009). While this research focused on the balance sheets of all young adults, those from lower-income backgrounds are arguably at greater risk for financial fragility and, thus, an important subgroup of interest, mitigating concerns about the 1996 SIPP's oversampling. The concern about excessive transitions between reference periods-an artifact of the 1996 SIPP survey design — has been mitigated by using information from the fourth and last reference month of the quarter, a recommendation by previous researchers ( $\mathrm{Ham}, \mathrm{Li}$, and Shore-Sheppard, 2009, and Moore et al., 2009). This meant using information from 12 quarters across the 4-year panel (the last reference month in the quarter), as opposed to all 48 months. In other words, young adults appeared to more precisely report life events such as the month they were married, but their recollection at the monthly level was "fuzzier" about seemingly minor life events such as opening a savings account until they were asked in person by the SIPP interviewers in the fourth reference month.

Another limitation is that the large sample sizes in the 1996 panel were useful to model the occurrence of rare events such as account acquisition and closure, but such large sample sizes also unexpectedly ruled out many estimation methods. For example, we considered using median regression as an analytic technique to model IHS-transformed liquid assets among the topical module sample (Pence, 2006); however, after one week of processing, R still had not returned output on our preliminary model. To test whether median regression was possible with a smaller sample size, we reran the preliminary model with a reduced sample and, indeed, results were produced. Given the lengthy time to produce output with such large samples, median regression was ruled out as a possible analytic technique and we instead used linear models with multilevel modeling and censored tobit regressions.

\section{CONCLUSION AND POLICY CONSIDERATIONS}

Automatic enrollment into a savings account is one consideration in terms of policy concerns regarding acquisition of savings accounts by young adults. Absent some external force such as homeownership or employment that requires an account, some young adults may never own a savings account (Benartzi and Thaler, 2007). Previous research has identified automatic enrollment as an important default: Nearly all participants open a savings account 


\section{Friedline, Johnson, Hughes}

in research studies in which the default leverages inertia and requires participants to opt out of account acquisition (Huang et al., 2013, and Nam et al., 2013).

Given that a savings account appears to be a gateway-and perhaps even a prerequisiteto asset diversification and accumulation, a related and second consideration is encouraging account acquisition by young adults to facilitate their development of a healthy balance sheet. Efforts to "bank the unbanked," so to speak, have focused on the importance of savings account acquisition in facilitating entry into the financial mainstream (FDIC, 2012). These efforts promote the use of safe and affordable financial products available from mainstream banks and credit unions as opposed to products from predatory payday lenders that may jeopardize balance sheets by charging excessive fees (FDIC, 2012, and Rhine and Greene, 2013). However, entry into the financial mainstream should not be the end in and of itself, particularly for young adults who are financially disadvantaged. Policies that promote transparency in savings account fees and lower barriers to acquisition, such as reduced or eliminated minimum balance requirements or maintenance fees, may indeed help young adults gain entry into the financial mainstream. Importantly, policies such as these may also serve to set young adults on a path to asset diversification and accumulation and to strengthen their balance sheets.

A third consideration relates to policies that encourage asset accumulation. All of the following contribute to the health of the balance sheet: a postsecondary education system built on debt (Assets and Education Initiative [AEDI], 2013); predatory mortgage lending practices (Agarwal et al., 2013); an economic recession that reduced net worth and raised unemployment rates (Kochhar, Fry, and Taylor, 2011, and Mishel et al., 2012); an expanding retail and service economy paying only minimum wage with few benefits (Aaronson, Agarwal, and French, 2012, and Carré and Tilly, 2012); and regressive tax policies that penalize individuals for accumulating assets (Cramer and Schreur, 2013). The tax code represents one of the most extensive and publicly accepted policies for asset diversification and accumulation, with a majority of the president's $\$ 536$ billion 2015 budget for saving and asset accumulation allocated through the tax code (Black, 2014). However, the tax code disproportionately benefits those from upper-income groups through subsidies on homeownership and retirement savings while neglecting certain groups who often lack such assets, such as young adults (Cramer, Black, and King, 2012). In part, this may be why a retirement account contributes such large predicted values to liquid asset accumulation as income quartiles increase. This "upside-down" asset policy in the tax code incentivizes and helps to maintain positions of financial advantage without necessarily helping young adults build assets (Woo, Rademacher, and Meier, 2010).

Real and substantial policy change is needed to stimulate asset diversification and promote accumulation among young adults, particularly since their current balance sheets may be an indicator of their lifetime financial security. While policy programs such as Individual Development Accounts and Child Development Accounts have been found to play important roles in the acquisition of a savings account and accumulation of assets (Boshara, 2012, and Sherraden, 1991), policies are also needed that are broader in scope and simultaneously address other vulnerabilities to young adults' balance sheets, such as student loans, predatory lending, income, and unemployment.

A final consideration relates to the implications of these results for young adults' balance sheets that also include debt and net worth. An underlying assumption of this research is that 
asset diversification and accumulation are desirable — and perhaps even reliable-indicators of a healthy balance sheet. While it is desirable for young adults to have opportunities to diversify their assets, diversification is not the only indicator of a healthy balance sheet, nor is it necessarily the outcome for which all young adults should strive. The composition of asset diversification and accumulated assets, debt, and net worth helps to determine the health of the balance sheet. Balance sheets by their very nature are complex: They incorporate debt that includes credit cards, vehicle loans, and mortgages of varying interest rates and policy terms plus assets that include money market, stock, and retirement accounts of varying restrictions and returns. As such, it is not enough to simply say that diversification and accumulation in and of themselves are indicators of a healthy balance sheet; where and how these diverse assets accumulate compared with debt also matter. 


\section{APPENDIXES}

\section{Appendix A: Descriptions of Control Variables}

Age. Young adults' age was a continuous variable ranging from 18 to 40 (TAGE).

Gender. Young adults' gender was measured based on their reports of being male or female (ESEX; female; male).

Race. Young adults' race included those who were white, black, Asian (including Pacific Islander), and Native American/First Peoples (ERACE). Given the low percentage in the sample who were Native American/First Peoples and their very similar estimates in the models compared with blacks, Native American/First Peoples were combined with blacks and identified as nonwhite (nonwhite; Asian; white).

Marital status. Marital status (EMS) was measured by asking young adults to report monthly whether they were married, widowed, divorced, separated, or never married. Responses were collapsed into married or not married categories (married; not married).

College enrollment. Young adults' college enrollment status (RENROLL) was measured by asking whether they were enrolled in school in the previous quarter. Young adults who were enrolled full- or part-time during the quarter were considered to have been enrolled in college, whereas those who were not enrolled in the quarter were considered to have not been enrolled (enrolled full-time; enrolled part-time; not enrolled).

Education level. Young adults were asked to report the highest grade completed or degree received each month, ranging from less than first grade to doctorate degree (EEDUCATE). Responses were collapsed to indicate having a primary school education through grade eight, some high school education through grade 12, a high school diploma, some college, or a four-year college degree or more (primary school; some high school; high school diploma; some college; college degree or more).

Employment status. Young adults were asked whether they were employed during the month (RMESR). Those who responded that they had a job for the entire month were coded as employed. Young adults who reported having a job for part of the month were coded as partially employed. Those without a job, including being absent without pay, laid off, or looking for work, were coded as unemployed (not employed; partially employed; employed). The change in young adults' employment status was tracked by using monthly information retrospectively over one previous calendar year. Young adults who were employed or unemployed without change between months were considered to be consistently employed or unemployed, respectively. Changes in status were observed when young adults moved from employed to unemployed or unemployed to employed.

Quarterly mean income. Young adults' total earned income was available for a given month (TPEARN), which was averaged across the months leading up to the fourth reference month in the quarter, winsorized (Cox, 2006), and transformed using the natural log to account for skewness. In the analyses predicting liquid assets, quarterly mean income was divided by 1,000 . 
Household relationship. Each quarter young adults were asked their relationship to the household reference person (ERRP) - the person for the household whose name appeared on the lease or mortgage and who was identified by the 1996 SIPP as the household head or person of reference. The 1996 SIPP recorded a range of relationship statuses, from a spouse or relative of the reference person to a housemate or other nonrelative. The range of relationships was categorized into young adults listed as the reference person, child of the reference person, relative, or nonrelative (reference person; child; relative; nonrelative). Forty-three percent of young adults were listed as the reference person, potentially indicating they were responsible for households of their own. Twenty-two percent of young adults reported they were the child of the reference person, potentially indicating they continued to reside with their families of origin. The remaining 35 percent reported they were relatives or nonrelatives of the household reference person. The change in household relationship status tracked young adults quarterly and retrospectively over one previous calendar year, identifying whether the status of young adults changed from being listed as a child, relative, or nonrelative to a household reference. Approximately 3 percent of the sample reported becoming a new reference person at some point during the panel. This change in household relationship status served as a proxy for young adults who became heads of households during the course of the panel (new reference person "yes"; not a new reference person "no").

Homeownership. Young adults were asked whether they lived in a home being purchased or currently owned or whether they rented or otherwise occupied the residence in which they lived $($ ETENURE; owned $=1$; rented or occupied $=0$ ). Their responses were measured monthly. However, we also expected the purchase or selling of a home could affect the amount of liquid assets available to young adults apart from simply being a homeowner. If they recently purchased a home, young adults may have spent down their liquid assets to make a down payment or repairs. As such, we modeled whether the quarterly change in young adults' homeownership over the previous preceding year related to their accumulated liquid assets (owned; purchased; sold; not a homeowner).

Geographic region. The 1996 SIPP asked young adults in which state their household resided (TFIPSST). States were recoded into geographic regions (South; North Central; West; Northeast; Elliott, 2013). Southern states included Alabama, Arkansas, Delaware, Florida, Georgia, Kentucky, Louisiana, Maryland, Mississippi, North Carolina, Oklahoma, South Carolina, Tennessee, Texas, Virginia, and West Virginia and Washington, DC. North Central states included Illinois, Indiana, Iowa, Kansas, Michigan, Minnesota, Missouri, Nebraska, Ohio, North Dakota, South Dakota, Wisconsin, and Wyoming. Western states included Alaska, Arizona, California, Colorado, Hawaii, Idaho, Montana, Nevada, New Mexico, Oregon, Utah, and Washington. Northeastern states included Connecticut, Maine, Vermont, Massachusetts, New Hampshire, New Jersey, New York, Pennsylvania, and Rhode Island. 
Friedline, Johnson, Hughes

\section{Appendix B}

\section{Generalized Additive Models Predicting Savings Account Ownership}

\begin{tabular}{|c|c|c|c|c|}
\hline \multirow[b]{2}{*}{ Covariates } & \multicolumn{2}{|c|}{ Model A } & \multicolumn{2}{|c|}{ Model B } \\
\hline & $\beta$ & SE & $\beta$ & SE \\
\hline \multicolumn{5}{|l|}{ Sex: Male } \\
\hline Female & $0.265^{* * *}$ & $(0.009)$ & $0.161^{* * *}$ & $(0.065$ \\
\hline \multicolumn{5}{|l|}{ Race: White } \\
\hline Nonwhite & $-0.480^{* * *}$ & $(0.013)$ & $-0.223^{* * *}$ & $(0.025$ \\
\hline Asian & $-0.158^{* * *}$ & $(0.021)$ & $-0.045^{* * *}$ & $(0.042$ \\
\hline \multicolumn{5}{|l|}{ Marital status: Not married } \\
\hline Married & $0.610^{* * *}$ & $(0.011)$ & $0.387^{* * *}$ & $(0.021)$ \\
\hline \multicolumn{5}{|c|}{ College enrollment: Full-time enrollment } \\
\hline Part-time enrollment & $-0.061^{* * *}$ & $(0.022)$ & 0.054 & $(0.044$ \\
\hline Not enrolled & $-0.436^{* * *}$ & $(0.015)$ & $-0.208^{* * *}$ & $(0.031$ \\
\hline \multicolumn{5}{|l|}{ Education level: Primary school } \\
\hline Some high school & $0.209 * * *$ & $(0.031)$ & -0.029 & $(0.058$ \\
\hline High school diploma & $0.965^{* * *}$ & $(0.028)$ & $0.408^{* * *}$ & $(0.052$ \\
\hline Some college & $1.362^{* * *}$ & $(0.028)$ & $0.630^{* * *}$ & $(0.052$ \\
\hline College degree or more & $1.743^{* * *}$ & $(0.029)$ & $0.815^{* * *}$ & $(0.054$ \\
\hline \multicolumn{5}{|l|}{ Employment status: Employed } \\
\hline Partially employed & $-0.237^{* * *}$ & $(0.018)$ & $-0.230 * * *$ & $(0.036$ \\
\hline Not employed & $-0.522^{* * *}$ & $(0.021)$ & $-0.382^{* * *}$ & $(0.038$ \\
\hline \multicolumn{5}{|c|}{ Household relationship to reference person } \\
\hline Child & $-0.681^{* * *}$ & $(0.015)$ & $-0.285^{* * *}$ & $(0.030$ \\
\hline Relative & $-0.044 * * *$ & $(0.010)$ & $0.060^{* * *}$ & $(0.020$ \\
\hline Nonrelative & $-0.412^{* * *}$ & $(0.022)$ & -0.053 & $(0.048$ \\
\hline \multicolumn{5}{|l|}{ New reference person: False } \\
\hline True & $-0.119^{* * *}$ & $(0.024)$ & 0.052 & $(0.045$ \\
\hline \multicolumn{5}{|c|}{ Change in homeownership: Not a homeowner } \\
\hline Homeowner & $-0.593^{* * *}$ & $(0.009)$ & $-0.286^{* * *}$ & $(0.018$ \\
\hline \multicolumn{5}{|l|}{ Geographic region: Northeast } \\
\hline West & $-0.161^{* * *}$ & $(0.013)$ & $-0.112^{* * *}$ & $(0.025$ \\
\hline North Central & $-0.088^{* * *}$ & $(0.012)$ & $-0.094^{* * *}$ & $(0.024$ \\
\hline South & $-0.457^{* * *}$ & $(0.012)$ & $-0.295^{* * *}$ & $(0.023$ \\
\hline Quarterly mean income spline 1 & $8.157^{* * *}$ & $(8.957)$ & $5.124^{* * *}$ & $(6.206$ \\
\hline Age spline 1 & $8.612^{* * *}$ & (8.788) & $8.079^{* * *}$ & $(8.772$ \\
\hline Savings account (lagged) & & & $5.081^{* * *}$ & $(0.016$ \\
\hline Constant & $-0.026^{* * *}$ & $(0.034)$ & -2.464 & $(0.065$ \\
\hline$R^{2}$ & 0.203 & & 0.764 & \\
\hline
\end{tabular}

NOTE: The results in this table are from the reference month sample ( $n=311,446$ person-month observations; $n=30,601$ individuals). Generalized additive models (GAMs) were performed on savings account ownership (regardless of whether young adults had an account during the fourth reference month) with and without a lagged account variable (Wood, 2004, 2006, 2011). The lagged account variable measured whether young adults owned a savings account in a preceding quarter. These models were used to determine how young adults first acquired an account, as opposed to the more sensitive "no-to-yes" transition measured by the multinomial logit models in Table 3. The question of predictors of account ownership logically preceded the question of account acquisition; however, account ownership was not a primary focus of our article. Thus, the GAM results are provided here. As shown, for the differences in estimates between Models A and B, the lagged savings account was a dominant predictor that depressed all other estimates and contributed an additional 56 percent to the variance in Model B. This finding provided some evidence to support the "stickiness" of savings account ownership across time. Young adults who had a savings account in one quarter were significantly more likely to maintain that account in the following quarter. ${ }^{* * *}$ indicates significance at the 1 percent level.

SOURCE: Unweighted data from the 1996 SIPP. 


\section{NOTES}

1 Xiao and Anderson (1997) also identify a third category of needs_"security" —or middle-level needs such as saving for a home or investing in human capital. Certificates of deposit, bonds, and money market accounts are financial products theorized to be consistent with meeting these middle-level needs.

2 While the United States as a whole experienced macroeconomic growth evidenced in part by expanded productivity (Jorgenson, Ho, and Stiroh, 2008), this growth did not necessarily translate into healthy balance sheets for all Americans. For instance, in the late 1990s, younger households headed by individuals 42 years of age or younger had about 29 percent of the median net worth held by older households; female heads of households had about 9 percent of the median net worth of male heads of households; black households had about 14 percent of the median net worth held by white households; and heads of households with high school educations had about 19 percent of the median net worth held by heads of households with college degrees (Friedline, Nam, and Loke, 2014).

3 The median value presented here for liquid assets was provided after the value was winsorized (Cox, 2006).

4 Censored median regression was considered to analyze liquid assets, debt, and net worth at the annual level (Koenker, 2008); however, running the model in a reasonable amount of time given the large number of observations was difficult with the $\mathrm{R}$ software. Censored median regression was abandoned as an analytic strategy after a single model was not produced within five days.

5 The effect of the censored tobit regression on the prediction of liquid assets can be seen by comparing estimates of "no account of any kind" from Model 6 with estimates from Models 4 and 5. The estimate for "no account of any kind" takes into consideration young adults who have no accounts and, thus, few to no accumulated liquid assets. In the censored tobit regression (Model 6), the estimate was steeper with a lower intercept or constant value $(\beta=0.580 ; \mathrm{SE}=0.285)$, indicating the technique's attempt to minimize the effects of these values.

6 Notably, when we examined the relationship between age and savings account ownership using a predicted probability scale from the generalized additive models (GAMs) that controlled for relevant factors, the age trend disappeared. In other words, using this method, young adults at age 40 or 30 were no more likely to own a savings account than young adults at age 20 . These figures are available from the authors upon request.

\section{REFERENCES}

Aaronson, Daniel; Agarwal, Sumit and French, Eric. "The Spending and Debt Response to Minimum Wage Hikes." American Economic Review, December 2012, 102(7), pp. 3111-39; doi:10.1257/aer.102.7.3111.

Agarwal, Sumit; Amromin, Gene; Ben-David, Itzhak; Chomsisengphet, Souphala and Evanoff, Douglas C. "Predatory Lending and the Subprime Crisis." NBER Working Paper No. 19550, National Bureau of Economic Research, October 2013; http://www.nber.org/papers/w19550.pdf.

Angrist, Joshua D. "Estimation of Limited Dependent Variable Models with Dummy Endogenous Regressors: Simple Strategies for Empirical Practice." Journal of Business and Economic Statistics, January 2001, 19(1), pp. 2-28.

Assets and Education Initiative. “Building Expectations, Delivering Results: Asset-Based Financial Aid and the Future of Higher Education," in William Elliott, ed., Biannual Report on the Assets and Education Field. Lawrence, KS: Assets and Education Initiative, 2013; http://save4ed.com/wp-content/uploads/2013/11/Full-Report.pdf.

Bell, Lisa; Burtless, Gary; Gornick, Janet and Smeeding, Timothy M. "Failure to Launch: Cross-National Trends in the Transition to Economic Independence," in Sheldon Danziger and Cecilia E. Rouse, eds., The Price of Independence: The Economics of Early Adulthood. Chap. 2. New York: Russell Sage Foundation, 2007, pp. 27-55.

Benartzi, Shlomo and Thaler, Richard. "Heuristics and Biases in Retirement Savings Behavior." Journal of Economic Perspectives, Summer 2007, 21(3), pp. 81-104.

Beutler, Ivan and Dickson, Lori. “Consumer Economic Socialization," in Jing Jian Xiao, ed., Handbook of Consumer Finance Research. Chap. 6. New York: Springer, 2008, pp. 83-102.

Black, Rachel. "Rebalancing the Scales: The 2015 Assets Budget." Washington, DC: New America Foundation, March 2014; http://newamerica.org/downloads/The_Assets_Budget_FY_2015.pdf. 


\section{Friedline, Johnson, Hughes}

Boshara, Ray. "From Asset Building to Balance Sheets: A Reflection on the First and Next 20 Years of Federal Assets Policy." CSD Perspective 12-24. Center for Social Development, Washington University in St. Louis, June 2012, http://csd.wustl.edu/Publications/Documents/P12-24.pdf.

Canova, Luigiana; Rattazzi, Anna Maria Mangenelli and Webley, Paul. "The Hierarchical Structure of Saving Motives." Journal of Economic Psychology, February 2005, 26(1), pp. 21-34; doi:10.1016/j.joep.2003.08.007.

Carasso, Adam and McKernan, Signe-Mary. "The Balance Sheets of Low-Income Households: What We Know about Their Assets and Liabilities." The Urban Institute, November 2007; http://aspe.dhhs.gov/hsp/07/PoorFinances/balance/report.pdf.

Carré, Françoise and Tilly, Chris. “Work Hours in Retail: Room for Improvement." Policy Paper No. 2012-012, W.E. Upjohn Institute for Employment Research, 2012; http://research.upjohn.org/up_policypapers/12/.

Cooper, Daniel. "Changes in U.S. Household Balance Sheet Behavior after the Housing Bust and Great Recession: Evidence from Panel Data." Public Policy Discussion Paper No. 13-6, Federal Reserve Bank of Boston, September 6, 2013; http://bostonfed.org/economic/ppdp/2013/ppdp1306.pdf.

Cox, Nicholas J. "WINSOR: Stata module to Winsorize a Variable." Boston College, Department of Economics, 2006; http://ideas.repec.org/c/boc/bocode/s361402.html\#related.

Cramer, Reid; Black, Rachel and King, Justin. "The Assets Report 2012: An Assessment of the Federal 'Asset-Building' Budget." Washington, DC: New America Foundation, April 2012; http://assets.newamerica.net/sites/newamerica.net/files/policydocs/AssetsReport2012.pdf.

Cramer, Reid and Schreur, Elliot. "Personal Savings and Tax Reform: Principles and Policy Proposals for Reforming the Tax Code." Washington, DC: New America Foundation, July 2013; http://assets.newamerica.net/sites/ newamerica.net/files/policydocs/Personal\%20Savings\%20and\%20Tax\%20Reform\%207-19-13-formatted.pdf.

Curtin, Richard T.; Juster, F. Thomas and Morgan, James N. "Survey Estimates of Wealth: An Assessment of Quality," in Robert E. Lipsey and Helen Stone Tice, eds., The Measurement of Saving, Investing, and Wealth. Chicago: University of Chicago Press, 1989, pp. 473-552; http://www.nber.org/chapters/c8126.pdf.

Czajka, John L.; Jacobson, Jonathan E. and Cody, Scott. Survey Estimates of Wealth: A Comparative Analysis and Review of the Survey of Income and Program Participation. Washington, DC: Mathematica Policy Research, August 22, 2003; http://www.ssa.gov/policy/docs/contractreports/SurveyEstimatesWealth.pdf.

De Brouwer, Philippe J.S. "Maslowian Portfolio Theory: An Alternative Formulation of the Behavioral Portfolio Theory." Journal of Asset Management, 2009, 9(6), pp. 359-65.

Fabozzi, Frank; Gupta, Francis and Markowitz, Harry M. "The Legacy of Modern Portfolio Theory." Journal of Investing, Fall 2002, 11(3), pp. 7-22; doi:10.3905/joi.2002.319510.

Federal Deposit Insurance Corporation. History of the 80s: An Examination of the Banking Crises of the 1980s and Early 1990s. Washington, DC: FDIC, 2007; https://www.fdic.gov/bank/historical/history/vol1.html.

Federal Deposit Insurance Corporation. 2011 FDIC National Survey of Unbanked and Underbanked Households. Washington, DC: Federal Deposit Insurance Corporation, September 2012; http://www.fdic.gov/householdsurvey/2012_unbankedreport.pdf.

Friedline, Terri; Despard, Mathieu R. and Chowa, Gina A.N. “Preventive Policy Strategy for Banking the Unbanked: Savings Accounts for Teenagers?" (Forthcoming in Journal of Poverty).

Friedline, Terri L. and Elliott, William. “Predicting Savings for White and Black Young Adults: An Early Look at Racial Disparities in Savings and the Potential Role of Children's Development Accounts (CDAs)." Race and Social Problems, July 2011, 3(2), pp. 99-118; doi:10.1007/s12552-011-9046-2.

Friedline, Terri and Elliott, William. “Connections with Banking Institutions and Diverse Asset Portfolios in Young Adulthood: Children as Potential Future Investors." Children and Youth Services Review, June 2013, 35(6), pp. 9941006; doi:10.1016/j.childyouth.2013.03.008.

Friedline, Terri; Elliott, William and Chowa, Gina A.N. "Testing an Asset-Building Approach for Young People: Early Access to Savings Predicts Later Savings." Economics of Education Review, Special Issue: Assets and Educational Attainment: Theory and Evidence, April 2013, 33, pp. 31-51; doi:10.1016/j.econedurev.2012.10.004. 
Friedline, Terri; Masa, Rainier D. and Chowa, Gina A.N. "Transforming Wealth: Using the Inverse Hyperbolic Sine (IHS) and Splines To Predict Youth's Math Achievement." Social Science Research, January 2015, 49, pp. 264-287; doi:10.1016/j.ssresearch.2014.08.018.

Friedline, Terri and Nam, IISung. "Savings from Ages 16 to 35: A Test To Inform Child Development Account Policy." Poverty and Public Policy, March 2014, 6(1), pp. 46-70.

Friedline, Terri; Nam, IISung and Loke, Vernon. "Households' Net Worth Accumulation Patterns and Young Adults' Financial Well-Being: Ripple Effects of the Great Recession?" Journal of Family and Economic Issues, September 2014, 35(3), pp. 390-410; doi:10.1007/s10834-013-9379-7.

Friedline, Terri and Song, Hyun-a. "Accumulating Assets, Debts in Young Adulthood: Children as Potential Future Investors." Children and Youth Services Review, September 2013, 35(9), pp. 1486-502. doi:10.1016/j.childyouth.2013.05.013.

Ham, John C.; Li, Xianghong and Shore-Sheppard, Lara. "Seam Bias, Multiple-State, Multiple-Spell Duration Models and the Employment Dynamics of Disadvantaged Women." NBER Working Paper No. 15151. National Bureau of Economic Research, July 2009; http://www.nber.org/papers/w15151.pdf.

Henningsen, Arne. "Estimating Censored Regression Models in R Using the censReg Package." University of Copenhagen, 2010; http://cran.r-project.org/web/packages/censReg/vignettes/censReg.pdf.

Henningsen Arne. "censReg: Censored Regression (Tobit) Models." R package version 0.5-20, August 20, 2013; http://CRAN.R-project.org/package=censReg.

Henningsen, Arne and Toomet, O. "maxLik: A package for maximum likelihood estimation in R." Computational Statistics, 2011, 26(3), pp. 443-58; doi:10.1007/s00180-010-0217-1.

Hogarth, Jeanne M. and O'Donnell, Kevin H. "If You Build It, Will They Come? A Simulation of Financial Product Holdings Among Low-to-Moderate Income Households." Journal of Consumer Policy, December 2000, 23(4), pp. 409-44; doi:10.1023/A:1007222700931.

Honoré, Bo E.; Kyriazidou, Ekaterini and Powell, J.L. "Estimation of Tobit-Type Models with Individual Specific Effects." Econometric Reviews, 2000, 19(3), pp. 341-66; doi:10.1080/07474930008800476.

Hosmer, David W. and Lemeshow, Stanley. Applied Logistic Regression. Second Edition. Hoboken, NJ: John Wiley and Sons, 2000.

Huang, Jin; Beverly, Sondra; Clancy, Margaret; Lassar, Terry and Sherraden, Michael. "Early Program Enrollment in a Statewide Child Development Account Program." Journal of Policy Practice, 2013, 12(1), 62-81; doi:10.1080/15588742.2012.739124

Huber, Peter J. "The Behavior of Maximum Likelihood Estimates Under Non-Standard Conditions," in Proceedings of the Fifth Berkeley Symposium on Mathematical Statistics and Probability. Berkeley, CA: University of California Press, 1967, pp. 221-33.

Jorgenson, Dale W.; Ho, Mun S. and Stiroh, Kevin J. "A Retrospective Look at the U.S. Productivity Growth Resurgence." Journal of Economic Perspectives, Winter 2008, 22(1), pp. 3-24.

Keister, L. "Religion and Wealth: The Role of Religious Affiliation and Participation in Early Adult Asset Accumulation." Social Forces, September 2003, 82(1), pp. 173-205.

Key, Clinton. "The Finances of Typical Households after the Great Recession," in Reid Cramer and T. Williams Shanks, eds., The Assets Perspective: The Rise of Asset Building and Its Impact on Social Policy. New York: Palgrave Macmillan, 2014, pp. 33-66.

King, Mervyn A. and Leape, Jonathan I. "Wealth and Portfolio Composition: Theory and Evidence." Journal of Public Economics, 1998, 69, pp. 155-93.

Koenker, Roger. “Censored Quantile Regression Redux." Journal of Statistical Software, July 2008, 27(6), pp. 1-25.

Kochhar, Rakesh; Fry, Richard and Taylor, Paul. “Wealth Gaps Rise to Record Highs between Whites, Blacks, Hispanics: Twenty-to-One." Washington, DC: Pew Charitable Trusts, Social and Demographic Trends, July 26, 2011; http://www.pewsocialtrends.org/2011/07/26/wealth-gaps-rise-to-record-highs-between-whites-blacks-hispanics/.

Maas, Cora J.M. and Hox, Joop J. “Robustness Issues in Multilevel Regression Analysis." Statistica Neerlandica, May 2004, 58(2), pp. 127-37. 


\section{Friedline, Johnson, Hughes}

Madrian, Brigitte C. and Shea, Dennis F. "The Power of Suggestion: Inertia in 401 (k) Participation and Saving Behavior." Quarterly Journal of Economics, 2001, 116(4), pp. 1149-87.

Markowitz, Harry. “Portfolio Selection.” Journal of Finance, December 1952, 7(1), pp. 77-91; doi:10.1111/j.1540-6261.1952.tb01525.x.

Maslow, Abraham H. "Some Theoretical Consequences of Basic Need-Gratification." Journal of Personality, June 1948, 16(4), pp. 402-16.

Maslow, Abraham H. Motivation and Personality. New York: Harper and Row, 1954.

Mishel, Lawrence; Bivens, Josh; Gould, Elise and Shierholz, Heidi. The State of Working America. Twelfth Edition. Ithaca, NY: Cornell University Press, 2012.

Mishkin, Frederic S. "The Household Balance Sheet and the Great Depression." Journal of Economic History, December 1978, 38(4), pp. 918-37.

Moore, Jeffrey; Bates, Nancy; Pascale, Joanne and Okon, Aniekan. “Tackling Seam Bias through Questionnaire Design," in Peter Lynn, ed., Methodology of Longitudinal Surveys. West Sussex, UK: John Wiley and Sons, Ltd., 2009, pp. 73-92.

Nam, Yunju; Kim, Youngmi; Clancy, Margaret; Zager, Robert and Sherraden, Michael. “Do Child Development Accounts Promote Account Holding, Saving, and Asset Accumulation for Children's Future? Evidence from a Statewide Randomized Experiment." Journal of Policy Analysis and Management, Winter 2013; 32(1), pp. 6-33; doi:10.1002/pam.21652.

Pence, Karen M. "The Role of Wealth Transformations: An Application to Estimating the Effect of Tax Incentives on Saving." Contributions to Economic Analysis and Policy, July 2006, 5(1), pp. 1-24.

Pinheiro, José; Bates, Douglas; DebRoy, Saikat; Sarkar, Deepayan and R Core Team. nlme: Linear and Nonlinear Mixed Effects Models: Version 3.1-118. Vienna, Austria: R Foundation for Statistical Computing, October 7, 2014; http://cran.r-project.org/web/packages/nlme/index.html.

R Core Team. R: A Language and Environment for Statistical Computing. Vienna, Austria: R Foundation for Statistical Computing, 2014; http://www.R-project.org.

Rank, Mark R. and Hirschl, Thomas A. "Estimating the Life Course Dynamics of Asset Poverty." CSD Working Paper No. 10-25. Center for Social Development, Washington University in St. Louis, 2010; http://csd.wustl.edu/Publications/Documents/WP10-25.pdf.

Raudenbush, Stephen W. and Bryk, Anthony S. Hierarchical Linear Models: Applications and Data Analysis Methods. Second Edition. London: Sage, 2002.

Rhine, Sherrie L.W. and Greene, William H. “Factors That Contribute to Becoming Unbanked." Journal of Consumer Affairs, Spring 2013, 47(1), pp. 27-45.

Serido, Joyce; Shim, Soyeon; Mishra, Anabhu and Tang, Chuanyi. "Financial Parenting, Financial Coping Behaviors, and Well-Being of Emerging Adults." Family Relations, October 2010, 59(4), pp. 453-64.

Shapiro, Thomas; Meschede, Tatjana and Osoro, Sam. “The Roots of the Widening Racial Wealth Gap: Explaining the Black-White Economic Divide." Research and Policy Brief February 2013. Institute on Assets and Social Policy, Brandeis University; http://iasp.brandeis.edu/pdfs/Author/shapiro-thomas-m/racialwealthgapbrief.pdf.

Sherraden, Michael. "Stakeholding: Notes on a Theory of Welfare Based Assets." Social Service Review, December 1990, 64(4), pp. 580-601.

Sherraden, Michael. Assets and the Poor: A New American Welfare Policy. Armonk, NY: M.E. Sharpe, 1991.

StataCorp. Stata Statistical Software: Release 12. College Station, TX: StataCorp LP, 2011.

Thaler, Richard H. and Sunstein, Cass R. Nudge: Improving Decisions about Health, Wealth, and Happiness. New York: Penguin Books, 2009.

Tobin, James. "Estimation of Relationships for Limited Dependent Variables." Econometrica, January 1958, 26, pp. 24-36.

U.S. Census Bureau. SIPP Users' Guide. Washington, DC: U.S. Census Bureau, Survey of Income and Program Participation, 2011; http://www.census.gov/programs-surveys/sipp/methodology/users-guide.html\#. 
White, Halbert. "Maximum Likelihood Estimation of Misspecified Models." Econometrica, January 1982, 50(1), pp. 1-25.

Wolff, Edward. "Recent Trends in the Size Distribution of Household Wealth." Journal of Economic Perspectives, Summer 1999, 12(3), pp. 131-50.

Woo, Beadsie; Rademacher, Ida and Meier, Jillien. "Upside Down: The $\$ 400$ Billion Federal Asset-Building Budget." Washington, DC: Corporation for Enterprise Development and the Annie E. Casey Foundation, 2010; http://cfed.org/assets/pdfs/UpsideDown_final.pdf.

Wood, Simon N. "Stable and Efficient Multiple Smoothing Parameter Estimation for Generalized Additive Models." Journal of the American Statistical Association, 2004, 99(467), pp. 673-86.

Wood, Simon N. Generalized Additive Models: An Introduction with R. Boca Raton, FL: Chapman and Hall/CRC, 2006.

Wood, Simon N. "Fast Stable Restricted Maximum Likelihood and Marginal Likelihood Estimation of Semiparametric Generalized Linear Models." Journal of the Royal Statistical Society B, January 2011, 73(1), pp. 3-36.

Xiao, Jing J. and Anderson, Joan Gray. "Hierarchical Financial Needs Reflected by Household Financial Asset Shares." Journal of Family and Economic Issues, Winter 1997, 18(4), pp. 333-55.

Xiao, Jing J. and Noring, Franziska, E. "Perceived Saving Motives and Hierarchical Financial Needs." Journal of Financial Counseling and Planning, 1994, 5, pp. 25-44.

Xiao, Jing J. and Olson, Geraldine I. "Mental Accounting and Saving Behavior." Home Economics Research Journal, September 1993, 22(1), pp. 92-109; doi:10.1177/004677749302200105. 
